\title{
Aktivni materijali koji se upotrebljavaju u superkondenzatorima
}

\author{
G. Ljubek ${ }^{a^{*}}$ i M. Kraljić Rokovićb \\ a Rudarsko-geološko-naftni fakultet, Pierottijeva 6, 10000 Zagreb \\ ${ }^{b}$ Fakultet kemijskog inženjerstva i tehnologije, Marulićev trg 19, 10000 Zagreb
}

Ovo djelo je dano na korištenje pod

\begin{abstract}
Sažetak
U posljednjih desetak godina napravljen je značajan iskorak u razvoju aktivnih materijala koji se upotrebljavaju u superkondenzatorima i u dizajniranju samog superkondenzatora. Stoga je u ovom radu dan kratak pregled istraživanja aktivnih materijala za superkondenzatore te je navedena njihova osnovna podjela temeljena na mehanizmima skladištenja naboja. Iz navedenih istraživanja može se zaključiti kako je za uspješan razvoj materijala nužno razumijevanje mehanizma skladištenja naboja i povezivanje strukturnih svojstava materijala s elektrokemijskim svojstvima. Spoznaje o mehanizmu skladištenja omogućuju ciljano dizajniranje materijala te kombiniranje elektroda s različitim mehanizmima, što u konačnici utječe na svojstva ali i na primjenu superkondenzatora. Najznačajniji materijali u ovom području su materijali temeljeni na ugljiku, vodljivi polimeri i metalni oksidi.

Ključne riječi

Aktivni materijal, kapacitet, metalni oksidi, pseudokapacitet, ugljik, vodljivi polimeri, superkondenzator
\end{abstract}

\section{Uvod}

U vrijeme kada je dostupnost fosilnih goriva sve manja, a klimatski i ekonomski problemi koji su nastali kao posljedica njihove pretjerane upotrebe sve veći, poseban naglasak se stavlja na alternativne izvore energije. U alternativne izvore energije, osim ostalog, spadaju i elektrokemijski spremnici energije čija su dva značajna predstavnika litij ionske baterije i superkondenzatori. ${ }^{1}$ Danas su litij ionske baterije na tržištu zastupljenije od superkondenzatora jer ih karakterizira velika gustoća energije, no zbog ograničene gustoće snage i broja ciklusa punjenja i pražnjenja, kao i ograničene količine raspoloživog litija, pokušavaju se pronaći alternativna rješenja. Upravo zbog toga znatna pažnja posvećuje se superkondenzatorima koji mogu uskladištiti manje gustoće energije u odnosu na baterije, ali su pogodni kad se zahtijevaju kratki i snažni strujni impulsi. Karakteristika superkondenzatora u velikoj mjeri ovisi o svojstvima elektrodnog materijala, kao i o izboru elektrolita. Materijal koji se komercijalno najčešće upotrebljava u superkondenzatorima je aktivni ugljik, međutim sve više se istražuju i pseudokapacitivni materijali. Oni imaju isti elektrokemijski odziv kao i aktivni ugljik, međutim princip skladištenja energije im je potpuno drugačiji. Naime, kod ugljika skladištenje naboja se temelji na formiranju elektrokemijskog dvosloja, ${ }^{2}$ dok se kod pseudokapacitivnih materijala skladištenje naboja temelji na faradejskim reakcijama. ${ }^{2,3}$ Kod navedenih razmatranja treba uzeti u obzir da ni jedan od navedenih materijala ne isključuje u potpunosti drugi mehanizam. Tako ugljik može sadržavati funkcionalne skupine na kojima se odvijaju i redoks-reakcije, dok na površini pseudokapacitivnih materijala gotovo uvijek dolazi do formiranja elektrokemijskog dvosloja. Posebnost pseudokapacitivnih materijala je u tome što mogu uskladi-

*Autor za dopisivanje: Gabrijela Ljubek, mag. ing. cheming.

e-pošta: gslavic@rgn.hr štiti veće količine energije u odnosu na aktivni ugljik. Konačan odabir materijala također ovisi o njihovoj kemijskoj i mehaničkoj stabilnost koja definira ukupan broj ciklusa punjenja i pražnjenja.

Što se tiče primjene, superkondenzatori su značajni u automobilskoj industriji i javnim prijevoznim sredstvima, gdje služe kao pomoćni izvor energije, ali isto tako bitni su i za skladištenje energije regenerativnog kočenja. Nadalje, Airbus 380 Jumbo Jet ugrađuje superkondenzatore iz sigurnosnih razloga, odnosno za otvaranje vrata u slučaju nezgode. Superkondenzatore je moguće upotrebljavati kod električnih kranova, različite prijenosne elektronike koja zahtijeva velike strujne impulse, kao i za stabilizaciju napona u vjetroelektranama, mikromrežama i električnim uređajima. ${ }^{4-6}$

U ovom radu dan je kratak uvod o superkondenzatorima, navedeni su mehanizmi skladištenja naboja, naveden je pregled elektrodnih materijala koji se upotrebljavaju u superkondenzatorima te osnovna podjela superkondenzatora. Materijali koji su posebno istaknuti u ovom radu su aktivni ugljik, $\mathrm{RuO}_{2}, \mathrm{MnO}_{2}, \mathrm{SnO}_{2}$, polipirol, polianilin i poli(3,4-etilendioksitiofen).

\section{Općenito o kondenzatorima}

Kondenzator je sustav koji se sastoji od dvije usporedne metalne ploče (elektrode) odvojene dielektrikom (izolatorom) a služi za pohranu električnog naboja, tj. električne energije. Električna energija se u kondenzatoru pohranjuje tako da se na vodljive elektrode, razdvojene dielektrikom, dovede napon prilikom čega se na jednoj elektrodi sakuplja pozitivni, a na drugoj negativni naboj. Pohrana energije u kondenzatoru je fizikalni proces i tijekom tog procesa 
ne dolazi do promjena u strukturi elektrodnog materijala, što omogućuje velik broj ciklusa punjenja i pražnjenja. ${ }^{7}$ Prema načinu izrade i primjene kondenzatori se dijele na elektrostatske, elektrolitske i elektrokemijske kondenzatore (superkondenzatore). Na slici 1 shematski su prikazane njihove konstrukcije.

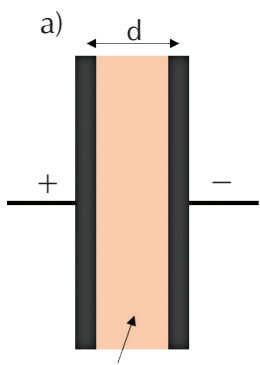

dielektrik

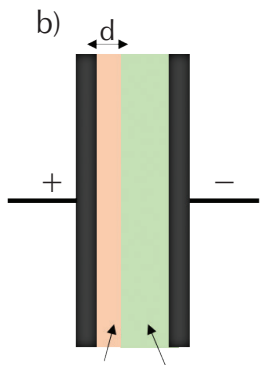

$\mathrm{Al}_{2} \mathrm{O}_{3}$ elektrolit

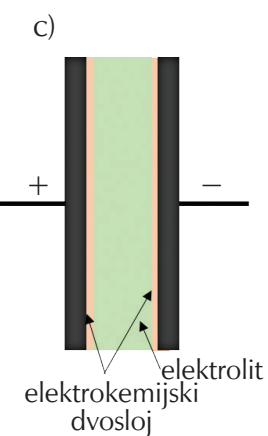

Slika 1 - Shematski prikaz a) elektrostatskog, b) elektrolitskog i c) elektrokemijskog kondenzatora (superkondenzator)

Fig. 1 -Schematic representation of the different capacitor types

Klasični elektrostatski uređaji koji se sastoje od dvije metalne ploče odvojene dielektrikom imaju najmanju gustoću energije u odnosu na ostale kondenzatore. Nešto veće vrijednosti gustoće energije postižu elektrolitski kondenzatori koji se najčešće sastoje od dvije aluminijske folije od kojih je jedna prekrivena tankim oksidnim slojem koji služi kao dielektrik. ${ }^{8}$ Komercijalni elektrostatski kondenzatori postižu kapacitete u rasponu od 5 pF do $100 \mu \mathrm{F}$ ovisno o vrsti dielektrika, dok komercijalni kondenzatori s aluminijevim oksidom postižu kapacitet koji se kreće $u$ rasponu od $1 \mu \mathrm{F}$ do $47 \mathrm{mF}$. U odnosu na njih superkondenzatori imaju mnogo veće kapacitete (do nekoliko tisuća farada), a time i veću gustoću energije.

Glavne karakteristike kondenzatora su specifični kapacitet, $C_{s}\left(F^{-1}\right)$, specifična energija, $W_{s}\left(W^{-1} ~ g^{-1}\right)$ i specifična snaga, $P_{\mathrm{s}}\left(\mathrm{Wg}^{-1}\right)$. Kapacitet, $C(\mathrm{~F})$, je sposobnost kondenzatora da skladišti naboj i on je konstantan u određenom području napona, te se može upotrijebiti za izračun uskladištenog naboja prema jednadžbi:

$$
\Delta Q=C \cdot \Delta U,
$$

gdje je $\Delta Q(C)$ količina naboja koja je uskladištena kad se primjeni određena naponska pobuda $\Delta U(\mathrm{~V})$.

Kapacitet pločastog kondenzatora koji se sastoji od dvije usporedne vodljive ploče istih dimenzija odvojene vakuumom na udaljenosti $d$ proporcionalan je površini ploča, a obrnuto proporcionalan njihovoj udaljenosti.?

$$
C=\varepsilon_{0} \frac{A}{d^{\prime}}
$$

gdje je $C$ kapacitet kondenzatora $(\mathrm{F}), \varepsilon_{0}$ dielektrična konstanta vakuuma $\left(\mathrm{F} \mathrm{m}^{-1}\right), A$ aktivna površina elektrode $\left(\mathrm{m}^{2}\right)$, $d$ razmak između elektroda $(\mathrm{m})$.
Kada je prostor između elektroda ispunjen dielektričnim medijem, kapacitet kondenzatora izravno je razmjeran dielektričnoj konstanti $(\varepsilon)$ i aktivnoj površini elektroda, a obrnuto proporcionalan razmaku između elektroda $(d):^{7}$

$$
C=\varepsilon \varepsilon_{0} \frac{A}{d}
$$

Iz jedn. (3) slijedi da je uz zadani dielektrik kapacitet veći što je veća aktivna površina elektroda, a razmak među njima manji. U slučaju superkondenzatora na svakoj od elektroda se formira elektrokemijski dvosloj unutar kojeg dolazi do razdvajanja naboja tako da se superkondenzator sastoji od dva serijski spojena kondenzatora. Prilikom formiranja elektrokemijskog dvosloja vrijednost $d$ se odnosi na debljinu dvosloja koja je nanometarskih dimenzija, što prema jedn. (3) znatno povećava vrijednost kapaciteta. Usto, upotreba elektrodnih materijala s poroznom strukturom povećava aktivnu površinu elektrode, što dodatno doprinosi povećanju kapaciteta. ${ }^{8,9}$ Nadalje, konstantan kapacitet znači da se naboj mijenja linearno s promjenom napona (tj. tijekom punjenja raste, a tijekom pražnjenja pada) te da je struja konstantna u određenom području napona (slika 2).
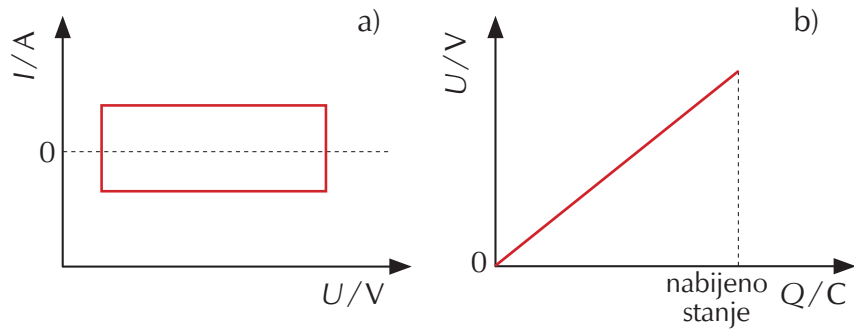

Slika 2 - a) Ovisnost struje o naponu i b) ovisnost napona o naboju kod superkondenzatora

Fig. 2 - a) Current vs. voltage characteristic, and b) voltage vs. charge characteristic of supercapacitor

Količina energije koja je uskladištena $W(\mathrm{Wh})$ može se dobiti integriranjem površine ispod pravca na slici 2 b).

$$
W=\int U d Q
$$

Uzevši u obzir jedn. (4) i (1) proizlazi:

$$
W=\frac{1}{2} C U^{2}
$$

Maksimalna snaga, $P_{\mathrm{m}}(\mathrm{W})$ superkondenzatora računa se prema sljedećoj relaciji:

$$
P_{\mathrm{m}}=\frac{U^{2}}{4 R^{\prime}}
$$

gdje je $R$ ekvivalentni serijski otpor uređaja $(\Omega)$. 


\section{Superkondenzatori}

Superkondenzatori su elektrokemijski pretvornici i spremnici energije. Prvi patent za elektrokemijski kondenzator datira iz 1957. godine kada je Becker dizajnirao kondenzator koji se sastojao od poroznih ugljikovih elektroda a elektrolit je bila sumporna kiselina. Dobiven je kapacitet od $6 \mathrm{~F}$ pri $1,5 \mathrm{~V} .{ }^{10}$ Sedamdesetih godina prošlog stoljeća započinje značajan razvoj i komercijalna primjena superkondenzatora. Ponajprije za vojne potrebe, a kasnije za primjenu u hibridnim električnim vozilima. ${ }^{11}$ Danas se superkondenzatori, osim za pokretanje hibridnih vozila, upotrebljavaju i za pokretanje autobusa, tramvaja, dizalica, turbina na vjetar, itd. U odnosu na baterije, superkondenzatori imaju dulji vijek trajanja tj. mogu ostvariti višestruko veći broj ciklusa punjenja/pražnjenja (> 100 000). U baterijama se energija pohranjuje kao rezultat kemijskih reakcija koje se odvijaju na elektrodama, te su ograničene na samo $\approx 1000$ ciklusa punjenja/pražnjenja, nakon čega dolazi do ireverzibilnih promjena materijala od kojeg su načinjene elektrode. Kod superkondenzatora ne dolazi do kemijskih niti do faznih promjena aktivnog materijala a, osim toga, elektrode ne sadrže teške metale poput nikla i olova, te su u odnosu na ostale elektrokemijske izvore električne energije ekološki prihvatljiviji. ${ }^{3}$ Dobar pokazatelj razlike supekondenzatora s ostalim uređajima za pohranu električne energije je Ragoneov dijagram (slika 3), koji pokazuje međusobnu ovisnost specifične snage $\left(\mathrm{W} \mathrm{kg}^{-1}\right)$ i specifične energije $\left(\mathrm{Wh} \mathrm{kg}^{-1}\right)$. Iz dijagrama je vidljivo da baterije imaju veliku specifičnu energiju (oko $250 \mathrm{Wh} \mathrm{kg}^{-1}$ ), ali i nisku specifičnu snagu (ispod $1000 \mathrm{~W} \mathrm{~kg}^{-1}$ ). Za razliku od baterija, kondenzatore karakterizira visoka specifična snaga (oko $10^{7} \mathrm{~W} \mathrm{~kg}^{-1}$ ) i niska specifična energija (ispod $0,06 \mathrm{Wh} \mathrm{kg}^{-1}$ ). Ako pogledamo položaj superkondenzatora u Ragoneovom dijagramu, oni se nalaze između klasičnih kondenzatora (elektrostatskih i elektrolitskih) te baterija i gorivnih članaka. $U$ odnosu na klasične kondenzatore, superkondenzatori mogu pohraniti veću količinu energije i imaju mnogo veću snagu od baterija. Jedan od najvećih ograničenja superkondenzatora u široj primjeni je činjenica da još uvijek pohranjuju manje

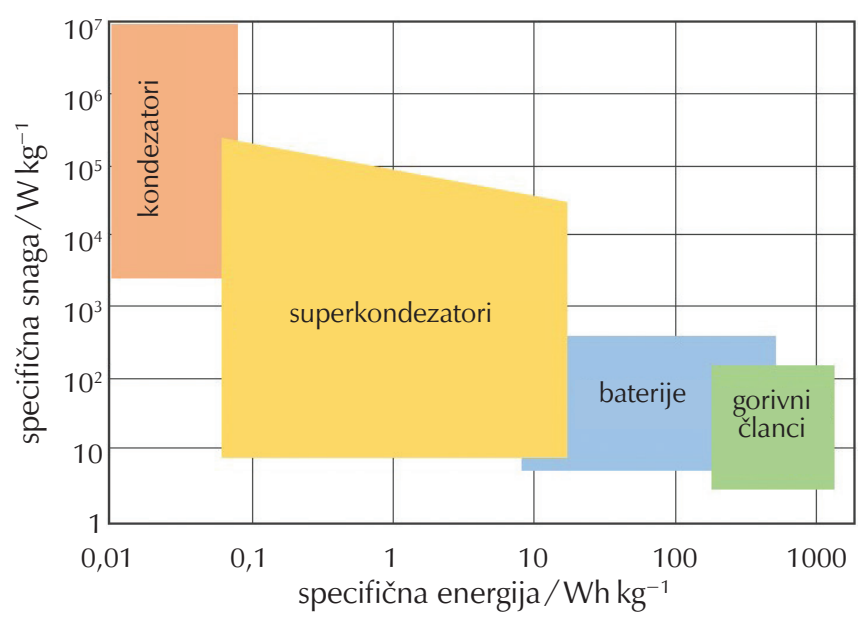

Slika 3 - Ragoneov dijagram

Fig. 3 - Ragone plot energije $\mathrm{u}$ odnosu na baterije. $U$ novije vrijeme taj nedostatak superkondenzatora pokušava se riješiti hibridnim uređajima kod kojih je jedna elektroda slična elektrodama koje se upotrebljavaju u baterijama, dok je druga elektroda karakteristična za superkondenzatore. ${ }^{12-15}$

Superkondenzatori se sastoje od dvije elektrode, elektrolita i separatora. Elektrode su najčešće sastavljene od strujnog kolektora na koji je nanesen aktivni materijal. Ako su obje elektrode načinjene od istog materijala, govorimo o simetričnim superkondenzatorima, u slučaju kad su elektrode načinjene od različitih materijala, riječ je o asimetričnim ili hibridnim superkondenzatorima.

Odabir elektrolita od iznimne je važnosti za širu primjenu superkondenzatora. Radni napon superkondenzatora određen je termodinamičkom stabilnošću elektrolita (pri većim naponima dolazi do njegova raspadanja), a specifična snaga i specifična energija ovise o radnom naponu (jedn. 5 i 6). Kao elektrolit upotrebljavaju se vodeni, organski ili polimerni elektroliti te u novije vrijeme ionske tekućine. Organski elektroliti mogu doseći veće radne napone od $3 \mathrm{~V}$ i više, a time i veću gustoću energije u odnosu na vodene elektrolite koji su ograničeni na 1,23 V. No ako se zahtjeva velika gustoća snage, organski elektroliti nisu dobar izbor zbog slabije vodljivosti, $20 \mathrm{mS} \mathrm{cm}^{-1}$, u odnosu na vodljivost vodenih elektrolita, $1 \mathrm{~S} \mathrm{~cm}^{-1}$. Također, praktična upotreba organskih elektrolita nailazi na izvedbene, ekonomske, sigurnosne i ekološke probleme. ${ }^{16}$ Organski elektroliti sastoje se od smjese otapala, kao što je acetonitril ili propilen karbonat, i odgovarajućih soli. Elektroliti na bazi propilen karbonata pokazuju mnogo manju električnu provodnost u odnosu na elektrolite s acetonitrilom, što kao rezultat ima manju izlaznu snagu. ${ }^{17}$ Od vodenih elektrolita najčešće se upotrebljavaju sumporna kiselina $\left(\mathrm{H}_{2} \mathrm{SO}_{4}\right)$ i kalijev hidroksid ( $\mathrm{KOH})$. Međutim, u novije vrijeme sve se više proučavaju ionske tekućine kao elektrolit u superkondenzatorima. lonske tekućine su niskotemperaturne taline soli koje se sastoje od velikog organskog kationa i organskog ili anorganskog aniona. ${ }^{18}$ Nisu korozivne, mogu se upotrebljavati pri vrlo visokim i niskim temperaturama, a napon ćelije može sezati do $6 \mathrm{~V}^{19}$ Elektrode su odvojene separatorom koji osigurava prolazak iona, no sprječava gibanje elektrona, čime se ostvaruje električna izolacija između elektroda. Odabir separatora ovisi o odabranom elektrolitu. Tako se polimerni ili celulozni separatori upotrebljavaju u slučaju organskih elektrolita, a kod vodenih elektrolita keramički ili separatori sa staklenim vlaknima. ${ }^{9}$

S obzirom na mehanizam skladištenja naboja i upotrijebljeni elektrodni materijal, superkondenzatori se dijele na elektrokemijske dvoslojne kondenzatore, pseudokondenzatore i hibridne kondenzatore.

\subsection{Elektrokemijski dvoslojni kondenzatori}

Elektrokemijski dvoslojni kondenzatori (engl. Electric Duble Layer Capacitor, EDLC) su superkondenzatori koji pohranjuju energiju tako da se formira elektrokemijski dvosloj na međufazi elektroda/elektrolit. ${ }^{20}$ Tijekom postupka pražnjenja superkondenzatora dolazi do izbijanja akumuliranog 
naboja na granici faza elektroda/elektrolit (slika 4). Takva elektrostatska pohrana naboja omogućuje velike brzine procesa punjenja i pražnjenja koji se može odvijati stotinama tisuća puta bez znatnih promjena količine naboja s primijenjenim potencijalom.

separator
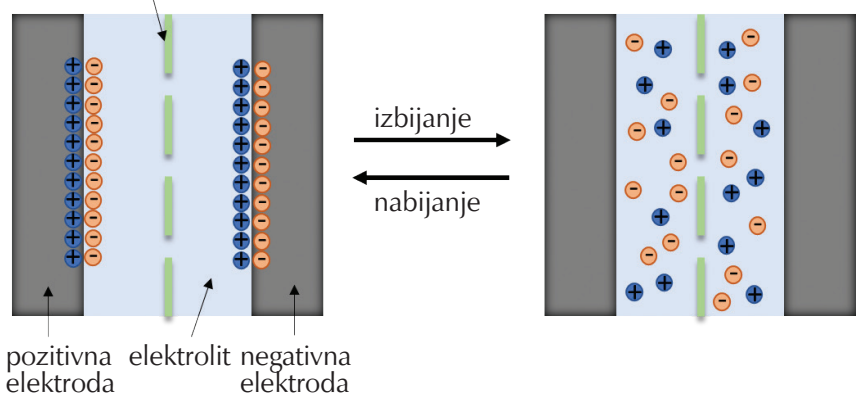

a elektrolit negativna

Slika 4 - Prikaz distribucije naboja za napunjen (lijevo) i prazan (desno) superkondenzator

Fig. 4 - Charge distribution of charged (left), and discharged (right) supercapacitor

Materijali koji se upotrebljavaju u elektrokemijskim dvoslojnim kondenzatorima su materijali na bazi ugljika kao što su aktivni ugljik, ugljikov aerogel, ugljikove nanocijevi, ugljikova nanovlakna te u novije vrijeme grafen i njegovi derivati. S ciljem postizanja velikih kapaciteta, razna istraživanja usmjerena su prema kontroli specifične površine i veličine pora ugljikovih materijala te povećanju električne provodnosti. Kod tih superkondenzatora broj ciklusa punjenja i pražnjenja je veći od 100000 a postižu snagu od 5 do $100 \mathrm{~kW} \mathrm{~kg}^{-1}$ te mogu uskladištiti energiju od 1 do $5 \mathrm{Wh} \mathrm{kg}^{-1} \cdot 2,21$

\subsection{Pseudokondenzatori}

Kod materijala koji se upotrebljavaju u pseudokondenzatorima unutar širokog područja potencijala odvijaju se brze i reverzibilne redoks-reakcije čiji je elektrokemijski odziv sličan onome koji se dobiva kod nabijanja/izbijanja elektrokemijskog dvosloja. Upravo se zbog toga rabi naziv "pseudokapacitivni materijali". To ujedno znači da se dobiva linearna ovisnost naboja o naponu, što inače nije karakteristika faradejskih reakcija. Ponašanje dobiveno za pseudokapacitivne materijale posljedica je specifičnih svojstava tih materijala odnosno termodinamike reakcija koje se odvijaju u materijalima. ${ }^{3}$ Najznačajniji predstavnici pseudokapacitivnih materijala su vodljivi polimeri (polianilin, polipirol i poli(3,4-etilendioksitiofen)) te oksidi prijelaznih metala poput $\mathrm{RuO}_{2}, \mathrm{MnO}_{2}, \mathrm{SnO}_{2}, \mathrm{i}_{2} \mathrm{O}_{5} \cdot{ }^{22,23}$ Pseudokondenzatore karakteriziraju veći specifični kapaciteti u odnosu na kapacitete koji se postižu kod EDLC, međutim specifična snaga i stabilnost su smanjene. Stoga je tijekom istraživanja vezanih uz te superkondenzatore velik izazov dizajniranje novih materijala koji posjeduju značajniju stabilnost te veću gustoću snage. Osim toga, kontinuirano se teži prema povećanju količine uskladištene energije. To se može postići kombinacijom različitih materijala, pri čemu se povećava napon odnosno širi područje potencijala unutar kojeg je određeni materijal aktivan. Sire područje aktivnosti osigurava veću količinu naboja, a samim time i veću energiju. Na primjer, kod superkondenzatora u kojem se upotrebljava $\mathrm{MnO}_{2}$ postižu se naponi od $0,6 \mathrm{~V}$ do $1 \mathrm{~V}_{1}{ }^{24}$ što znači da se elektrokemijska aktivnost svake pojedine elektrode ograničava na 0,3 do $0,5 \mathrm{~V}$. Jedan od načina kako se materijal može bolje iskoristiti je da se u superkondenzatoru upotrebljavaju elektrode od različitih materijala. Tako se kombinacijom $\mathrm{MnO}_{2}$ kao pozitivne elektrode i poli(3,4-etilendioksitiofena) kao negativne elektrode mogu postići naponi od 1,8 V, što znači da je svaki materijal aktivan unutar područja potencijala od $0,9 \mathrm{~V}$. U slučaju superkondenzatora kod kojeg su obje elektrode od $\mathrm{MnO}_{2}$ određena je specifična energija od 2 do $4 \mathrm{Wh} \mathrm{kg}^{-1}$, dok je u slučaju superkondenzatora s različitim elektrodama zabilježena specifična energija od $13 \mathrm{Wh} \mathrm{kg}^{-1^{*}} .{ }^{24}$

\subsection{Hibridni superkondenzatori}

Hibridni superkondenzatori su kombinacija EDLC i pseudokondenzatora. To su asimetrični superkondenzatori gdje je jedna elektroda napravljena od materijala s kapacitivnim ponašanjem, a druga od materijala kod kojeg se odvija pseudokapacitivna reakcija. Kao što je već spomenuto kod asimetričnih pseudokapacitivnih kondenzatora, kombinacijom različitih materijala pokušava se povećati količina uskladištene energije tako da se poveća potencijalno područje u kojem je materijal aktivan. Kod kombinacije negativne elektrode od aktivnog ugljika i pozitivne elektrode od pseudokapacitivnog materijala, osim što je povećano potencijalno područje, javljaju se i dodatni efekti. Naime, pseudokapacitivni materijal najčešće ima veći kapacitet pa vrijedi $\left(C_{+}\right) \gg\left(C_{-}\right)$. U tom slučaju prema izrazu za superkondenzator:

$$
1 / C=1 / C_{-}+1 / C_{+}
$$

proizlazi da je $C \approx C_{-}$. U slučaju EDLC superkondenzatora, gdje su obje elektrode od ugljika $C_{+}=C_{-}$, prema izrazu (7) proizlazi $C=C_{-} / 2$. Stoga se može zaključiti da će sama kombinacija dvije različite elektrode dovesti do porasta ukupnog kapaciteta.

Jedan od materijala koji se upotrebljava kao negativna elektroda je $\mathrm{MnO}_{2}$. Gao i sur. ${ }^{25}$ sintetizirali su kompozit $\mathrm{MnO}_{2} /$ aktivni ugljik kao pozitivnu elektrodu, dok je čisti aktivni ugljik bio negativna elektroda. Naime, kompozit $\mathrm{MnO}_{2}$ i aktivnog ugljika pokazao je znatno bolju električnu provodnost u odnosu na čisti $\mathrm{MnO}_{2}$, pa je samim time dobiven reverzibilniji odziv. Osim toga, prisustvo $\mathrm{MnO}_{2}$ znatno je povećalo vrijednosti specifičnog kapa-

\footnotetext{
* U znanstvenoj literaturi energija i snaga se označavaju kao specifične vrijednosti, odnosno izražavaju se po masi aktivnog materijala. Prilikom usporedbe kapaciteta različitih materijala treba biti oprezan jer su ponekad dani kapaciteti jedne elektrode koja je ispitana u troelektrodnom sustavu, a ponekad kapaciteti superkondenzatora koji se sastoji od dvije elektrode. Izraz za ukupni kapacitet superkondenzatora kod kojeg su mase obje elektrode iste definira se kao $1 / C=1 / C_{-}+1 / C_{+}$te se očekuje dvostruko manji kapacitet od onog dobivenog u troelektodnom sustavu. Ako se dodatno uzme u obzir mase obje elektrode, tada je kapacitet superkondenzatora četiri puta manji od kapaciteta elektrode koja je ispitana u troelektrodnom sustavu.
} 
citeta. Zhao i sur. ${ }^{26}$ pripremili su hibridni superkondenzator na bazi kompozita $\mathrm{MnO}_{2}-\mathrm{Pd}-\mathrm{CNT}-\mathrm{Ni}$ pjena visokog specifičnog kapaciteta od 559,1 $\mathrm{Fg}^{-1}$. Hibridni superkondenzator sastavljen je od $\mathrm{MnO}_{2}$ kompozita kao pozitivne elektrode, aktivnog ugljika kao negativne elektrode te uz ionsku tekućinu kao elektrolit. Pokazalo se da je dobivena velika gustoća energije $\left(78,4 \mathrm{Wh} \mathrm{kg}^{-1}\right)$ i gustoća snage $\left(12,7 \mathrm{~kW} \mathrm{~kg}^{-1}\right)$.

Jedna od izvedbi hibridnih superkondenzatora je kombinacija elektrode baterijskog tipa (npr. elektroda $\mathrm{Ni}(\mathrm{OH})_{2}$ ili $\left.\mathrm{PbO}_{2}\right)^{27}$ i elektrode superkondenzatora (aktivni ugljik). Karakteristika elektroda koje se upotrebljavaju u baterijama je da se redoks-reakcija odvija kod određenog potencijala, dok se kod pseudokapacitivnih elektroda u superkondenzatoru reakcija odvija u širokom području potencijala. S obzirom na to da jedna elektroda u navedenom slučaju ne pokazuje ponašanje tipično za superkondenzatore kod te vrste uređaja, tijekom punjenja i pražnjenja, bit će dobivena karakteristika koja nije tipična za superkondenzatore. Prvi takav uređaj patentirali su Varakin i sur. 1995 godine. ${ }^{28}$ Jedan od hibridnih uređaja koji privlači pažnju znanstvenika u novije vrijeme je Zn-ion hibridni superkondenzator. Kod njega se upotrebljava Zn kao negativna elektroda, dok je aktivni ugljik pozitivna elektroda. Tang $i$ sur. ${ }^{29}$ sastavili su navedeni superkondenzator koji je pokazao kapacitete od $170 \mathrm{~F} \mathrm{~g}^{-1}$ pri struji od $0,1 \mathrm{~A} \mathrm{~kg}^{-1}$, gustoću energije $52,7 \mathrm{Wh} \mathrm{kg}^{-1}$ i gustoću snage $1,7 \mathrm{~kW} \mathrm{~kg}^{-1}$ te stabilnost od 91 \% tijekom 20000 ciklusa punjenja i pražnjenja.

lako se kod hibridnih superkondenzatora očekuje povećanje gustoće energije, tek prelaskom na nevodene elektrolite učinjen je značajan pomak u povećanju gustoće energije zahvaljujući višim radnim naponima koje oni mogu postići. ${ }^{1}$ Prvi takav hibridni uređaj bio je kombinacija aktivnog ugljika i $\mathrm{Li}_{4} \mathrm{Ti}_{5} \mathrm{O}_{12} \mathrm{u}$ acetonitrilu. ${ }^{30}$

\section{Materijali za elektrokemijske dvoslojne kondenzatore}

Aktivni ugljik je jedan od najčešće rabljenih elektrodnih materijala u komercijalnim superkondenzatorima. Razlog tome je velika raspoloživost sirovine, relativno niska cijena, razvijena tehnologija proizvodnje te velika aktivna površina. Djelatna površina običnog ugljičnog praška je oko $100 \mathrm{~m}^{2} \mathrm{~g}^{-1}$, a aktiviranog od $1000 \mathrm{~m}^{2} \mathrm{~g}^{-1}$ do $3000 \mathrm{~m}^{2} \mathrm{~g}^{-1} \cdot{ }^{31}$ Osim aktivnog ugljika intenzivno se istražuju i ugljikove nanocijevi, ugljikov aerogel i grafen.

\subsection{Aktivni ugljik}

Aktivni ugljik dobiva se postupkom pirolize iz ugljikom bogatih organskih prekursora kao što su npr. kokosove ljuske. Osim prirodnih materijala i sintetski materijali poput polimera mogu također poslužiti kao prekursori. Dodatna aktivacija materijala, koja može biti kemijska aktivacija plinovima, rezultira poroznom strukturom, pri čemu nastaju mikropore $(<2 \mathrm{~nm})$, mezopore $(2-50 \mathrm{~nm})$ i makropore $(>50 \mathrm{~nm})$, kao što je prikazano na slici $5 .^{32}$ Kemijska aktivacija aktivnog ugljika provodi se dodatkom različitih kemikalija, nakon čega se smjesa zagrijava na temperaturama od 400 do $1000{ }^{\circ} \mathrm{C}$. Aktivacija plinovima provodi se pomoću vodene pare ili $\mathrm{CO}_{2}$ pri temperaturama od 800 do $1000{ }^{\circ} \mathrm{C}$. Većina površine se odnosi na mikropore koje su slabo ili uopće nisu pristupačne ionima elektrolita, posebno organskim, te se ne mogu iskoristiti u procesu formiranja elektrokemijskog dvosloja. Materijali bogati mezoporama imaju veće vrijednosti kapaciteta jer je pokazano da mezopore omogućavaju lakšu difuziju iona do aktivne površine. ${ }^{33}$

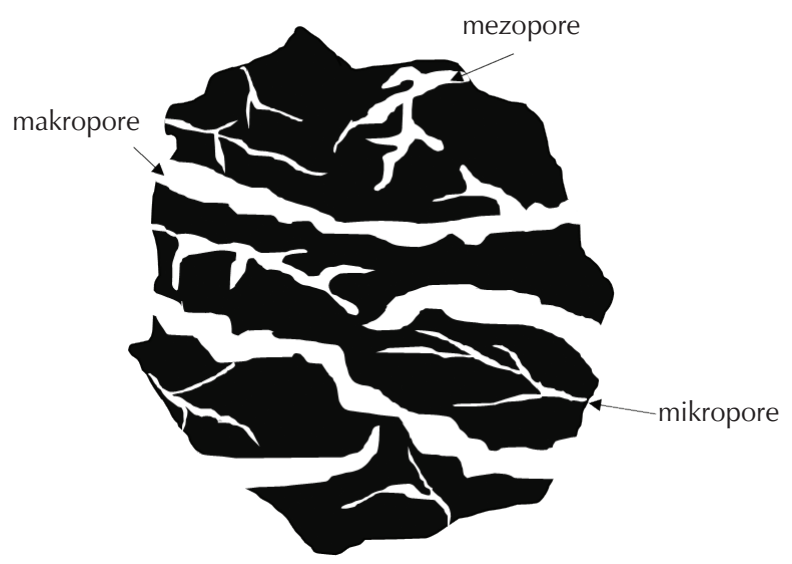

Slika 5 - Prikaz strukture aktivnog ugljika

Fig. 5 - Structure of activated carbon

U novije vrijeme intenzivnije se proučava dobivanje aktivnog ugljika iz biomase, ponajprije zbog niske cijene i lake dostupnosti. Inal i sur. ${ }^{34}$ pripremili su aktivni ugljik iz demineraliziranog otpada koji nastaje prilikom obrade sjemenki kima. Ispiranje otpada pomoću kiselina s ciljem uklanjanja minerala u konačnici je rezultiralo dobivanjem aktivnog ugljika veće specifične površine $\left(1472 \mathrm{~m}^{2} \mathrm{~g}^{-1}\right)$ od one koja bi bila dobivena uporabom materijala koji nije bio tretiran kiselinama. Od aktivnog materijala izrađene su elektrode koje pokazuju specifični kapacitet od $155 \mathrm{Fg}^{-1}$, pri gustoći struje od 1,5 $\mathrm{mA} \mathrm{cm}^{-2}$, što je veća vrijednost u usporedbi s $117 \mathrm{~F} \mathrm{~g}^{-1}$ za elektrode kod kojih je početni materijal bio netretirani prekursor. Osim toga, uklanjanjem minerala iz prekursora, smanjen je unutarnji otpor materijala, što doprinosi poboljšanju ukupnih svojstava elektrode. Zhu $i$ sur. ${ }^{35}$ proučavali su utjecaj različitih aktivacijskih metoda na morfologiju i elektrokemijske karakteristike dobivenog aktivnog ugljika. Aktivni ugljik sintetiziran je pirolizom iz biomase ginko lista kao prekursora te je naknadno aktiviran pomoću $\mathrm{KOH}, \mathrm{ZnCl}_{2}$ ili $\mathrm{H}_{3} \mathrm{BO}_{3}$. Materijal aktiviran kalijevom lužinom pokazao je najveći specifični kapacitet, $374 \mathrm{Fg}^{-1}$ pri $0,5 \mathrm{Ag}^{-1}$ u $1 \mathrm{M} \mathrm{H}_{2} \mathrm{SO}_{4}$ koji je znatno veći u odnosu na kapacitete sličnih ugljikovih materijala. Morfologija nakon aktivacije kalijevom lužinom ukazuje na prisutnost većih količina međusobno povezanih makropora. 


\subsection{Grafen}

Grafen je monosloj $\mathrm{sp}^{2}$-hibridiziranih ugljikovih atoma povezanih u heksagonalnu strukturu. On je osnovna gradivna jedinica u grafitu gdje su grafenski listovi usporedno povezani slabim van der Waalsovim interakcijama u slojevitu strukturu (slika 6) Grafen su prvi put izolirali A. Geim i K. Novoselov 2004. godine ${ }^{36}$ te za isto otkriće 2010. godine dobili Nobelovu nagradu za fiziku. Grafen odlikuje odlična električna provodnost te velika specifična površina, što ga čini pogodnim za primjenu kod superkondenzatora. ${ }^{37}$

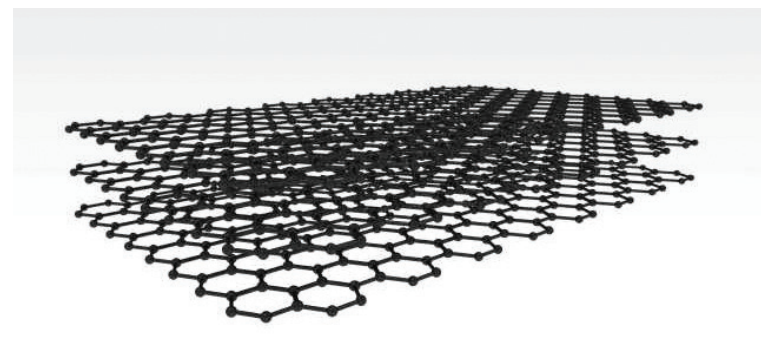

Slika 6 - Kristalna struktura grafita koju čine usporedno povezani listovi grafena

Fig. 6 - Crystal structure of graphite

Do sada su razvijene različite metode sinteze grafena, poput mehaničkog raslojavanja grafita, epitaksijalnog rasta na $\mathrm{SiC}$, sinteza grafena iz prekursora u plinovitom stanju na $\mathrm{Ni}$ ili $\mathrm{Cu}$, elektrokemijsko raslojavanje grafite te kemijska sinteza iz otopine uz grafit kao prekursor. ${ }^{38,39} \mathrm{U}$ dosadašnjim istraživanjima pokazalo se da je kemijska metoda sinteze grafena najuspješnija za pripremu velikih količina produkta koji bi se mogao upotrijebiti kao aktivni elektrodni materijal u superkondenzatorima.

Teoretska vrijednost specifične površine grafena je $2620 \mathrm{~m}^{2} \mathrm{~g}^{-1}, 40$ a teoretski specifični kapacitet oko $550 \mathrm{~F} \mathrm{~g}^{-1} .^{41}$ Dobivanje tih vrijednosti u praksi se pokazalo problematičnim s obzirom a to da grafenski listovi teže aglomeraciji i povezivanju u grafitnu strukturu. Kako bi se približili navedenim teoretskim vrijednostima, za specifičnu površinu i kapacitet potrebno je sintetizirati materijal manje sklon aglomeraciji. Stoga se pri odabiru metode sinteze prednost daje kemijskoj sintezi grafena jer se na taj način dobiva grafen s kisikovim funkcionalnim skupinama koje smanjuju aglomeraciju. Pažljivom kontrolom parametara tijekom sinteze moguće je kontrolirati količinu kisikovih funkcionalnih skupina. U kemijskoj sintezi provodi se oksidacija grafita jakim oksidansima poput smjese $\mathrm{HNO}_{3}$, koncentrirane $\mathrm{H}_{2} \mathrm{SO}_{4}$ i $\mathrm{KClO}_{3}$ ili smjese koncentrirane $\mathrm{H}_{2} \mathrm{SO}_{4}, \mathrm{NaNO}_{3}$ i $\mathrm{KMnO}_{4}$ i na taj način se u strukturu grafita uvode funkcionalne skupine koje materijal čine hidrofilnim i šire udaljenost među slojevima. Pri tome nastaje grafitov oksid koji se primjenom ultrazvuka raslojava na monoslojni grafenov oksid (GO). U odnosu na grafen taj oblik pokazuje lošiju električnu provodnost jer zbog velikog broja kisikovih funkcionalnih skupina posjeduje $\mathrm{sp}^{3}$-defekte. No upravo prisutnost kisikovih funkcionalnih skupina sprječava aglomeraciju i omogućuje dobru toplji- vost GO u vodi i organskim otapalima. GO zbog svoje loše električne provodnosti nije pogodan kao elektrodni materijal, već je potrebno provesti njegovu redukciju.

U dosadašnjim istraživanjima pokazano je da redukcijom dolazi do uklanjanja kisikovih funkcionalnih skupina, povećanja broja ugljikovih atoma koji su $\mathrm{sp}^{2}$-hibridizirani te u konačnici povećanja električne provodnosti materijala. ${ }^{42}$ U većini slučajeva reducirani oblik zadržava određenu količinu kisikovih funkcionalnih skupina. Neke od metoda kojima je moguće reducirati GO su termalna redukcija, mikrovalna, elektrokemijska i kemijska redukcija. Najčešće se provodi kemijska redukcija pomoću reagensa kao što su hidrazin, natrij bor tetrahidrid i askorbinska kiselina, koja se u novije vrijeme pokazala kao dobra alternativa hidrazinu. $^{43-45}$ Svaka od navedenih metoda redukcije ima prednosti, ali i brojne nedostatke, te se još uvijek radi na razvoju najpogodnijih uvjeta redukcije kojima bi se uklonile kisikove funkcionalne skupine. Kao elektrodni materijal za elektrokemijske superkondenzatore grafen su prvi upotrijebili Vivekchand $i$ sur. 2008. godine. ${ }^{46}$ Termalnim raslojavanjem grafitova oksida pri temperaturi od $1050{ }^{\circ} \mathrm{C}$ dobili su grafenski materijal specifične površine od $925 \mathrm{~m}^{2} \mathrm{~g}^{-1}$. Izmjereni specifični kapaciteti iznosili su $117 \mathrm{Fg}^{-1} \mathrm{u}$ vodenom elektrolitu i $75 \mathrm{~F} \mathrm{~g}^{-1}$ u ionskoj tekućini. Wanga $i$ sur. ${ }^{47}$ su 2009. godine proveli redukciju GO plinovitim hidrazinom pri sobnoj temperaturi u trajanju od $72 \mathrm{~h}$. Na taj način smanjen je stupanj aglomeracije grafenskih listova, te je dobiven specifični kapacitet superkondenzatora od $205 \mathrm{~F} \mathrm{~g}^{-1}$ u vodenom elektrolitu. Dobivena specifična snaga sastavljenog superkondenzatora iznosila je $10 \mathrm{~kW} \mathrm{~kg}^{-1}$ a specifična energija 28,5 Wh kg-1. Nakon 1200 ciklusa punjenja i pražnjenja zadržano je 90 \% nazivnog kapaciteta. Daljnja znanstvena istraživanja išla su upravo u smjeru dodatnog optimiranja procesa redukcije GO. Feng $i$ sur. ${ }^{48}$ predložili su redukciju GO upotrebom $\mathrm{Na}-\mathrm{NH}_{3}$ (elementarni natrij otopljen u tekućem amonijaku) kao reducensa. $\cup$ odnosu na postupak s hidrazinom, gore navedena redukcija je ekološki prihvatljivija, jednostavnija i brža te se odvija pri niskim temperaturama. GO film se uranja u Na$\mathrm{NH}_{3}$ otopinu, gdje je već nakon 1 min vidljiva promjena u boji filma, iz smeđe u crnu, što ukazuje na uspješno provedenu redukciju i dobivanje reduciranog GO (rGO) (udio kisikovih funkcionalnih skupina nakon redukcije iznosio je 5,6\%). Tako dobivene rGO filmove upotrebljavali su izravno kao elektrode u superkondenzatorima. Dobiven je specifični kapacitet od $263 \mathrm{Fg}^{-1}$. Mikrovalna redukcija GO još je jedna brza metoda redukcije čija je glavna prednost ravnomjerno zagrijavanje uzorka pri atmosferskim uvjetima. Zhu i sur. ${ }^{49}$ primjenjivali su tu metodu za dobivanje grafena. Pokazali su da je moguće dobiti specifične kapacitet i do $191 \mathrm{Fg}^{-1}$ uz $\mathrm{KOH}$ kao osnovni elektrolit.

Drugi smjer $\mathrm{u}$ istraživanju grafenskih materijala za superkondenzatore dali su znanstvenici koji su interkalirati neke druge materijale u grafensku mrežu, kao što su površinski aktivne tvari, ${ }^{50}$ ugljikovo crnilo, ${ }^{51,52}$ ugljikove nanocije$\mathrm{vi}^{53,54}$ metalne nanočestice poput platine ${ }^{55}$ ili ispredena vlakna $\mathrm{Fe}_{2} \mathrm{O}_{3}{ }^{56} \mathrm{Na}$ taj način postiže se otvorenija struktura grafena i lakša difuzija iona iz elektrolita, što rezultira znatnim poboljšanjem elektrokemijskih svojstava.

Zhang i sur. ${ }^{50}$ proučavali su utjecaj različitih površinski aktivnih tvari na stabilnost GO i rGO. Površinski aktivne tvari 
interkalirali su u GO tako da su pomiješali $100 \mathrm{ml}$ otopine GO s $100 \mathrm{ml}$ otopine surfaktanta te dobivenu smjesu miješali 3 dana pri sobnoj temperaturi. Dobiveni produkt je filtriran te dodatno reduciran hidraznom. Utvrđeno je da su u prisustvu površinski aktivnih tvari dobiveni veliki specifični kapaciteti. Tako je pri gustoći struje od $1 \mathrm{Ag}^{-1} \mathrm{u}$ $2 \mathrm{~mol} \mathrm{dm}^{-3} \mathrm{H}_{2} \mathrm{SO}_{4}$ zabilježena vrijednost od $194 \mathrm{Fg}^{-1}$, a u ionskoj tekućini $144 \mathrm{~F} \mathrm{~g}^{-1}$. Dobiveni kapaciteti posljedica su povećanog kvašenja površine elektrode u elektrolitu te većeg razmaka među grafenskim listovima.

3D grafenski materijali još su jedno rješenje za sprječavanje aglomeracije grafenskih listova, čime se znatno povećava aktivna površina te učinkovitost upotrebe grafena za pohranu naboja. Grafenski hidrogelovi nastaju slaganjem 2D grafenskih listova u različite 3D makrostrukture pri čemu se zadržavaju svojstva individualnih grafenskih listova. Metoda koja se primjenjuje za dobivanje tih materijala je hidrotermalna redukcija GO. Kada je koncentracija GO veća od $1 \mathrm{mg} \mathrm{ml}^{-1}$, pri hidrotermalnim uvjetima spontano dolazi do redukcije GO i formiranja grafenskog hidrogela. Ustanovljeno je kako grafenski hidrogelovi sadrže 97,4 \% vode i 2,6 \% grafena a električna provodnost im iznosi $5 \cdot 10^{-5} \mathrm{~S} \mathrm{~m}^{-1}$. Porozna struktura s makroskopskim porama posljedica je razvijanja $\mathrm{CO}_{2}$ prilikom formiranja hidrogela. ${ }^{57,58}$

Hidrotermalnom redukcijom GO dobiven je grafenski hidrogel specifične površine od $964 \mathrm{~m}^{2} \mathrm{~g}^{-1}$, od kojeg su načinjene elektrode za superkondenzator. Bitno je za napomenuti da za izradu elektrode nisu upotrijebljena veziva i aditivi. Dobiven je specifični kapacitet od $152 \mathrm{~F} \mathrm{~g}^{-1}$ pri $20 \mathrm{mV} \mathrm{s}^{-1}$ koji je oko 50 \% veći od kapaciteta superkondenzatora načinjenog od aglomeriranih čestica rGO, testiranog pri istim uvjetima. ${ }^{59}$ Nadalje, hidrotermalnom redukcijom u prisustvu hidrazina poboljšana je vodljivost grafenova hidrogela. Dobiven je specifični kapacitet od $220 \mathrm{~F} \mathrm{~g}^{-1}{ }^{60} \mathrm{U}$ sličnom istraživanju pokazano je kako se hidrotermalnom redukcijom u prisustvu antioksidansa ekstrakta lista masline postižu kapaciteti od $50 \mathrm{Fg}^{-1} \cdot{ }^{61} \mathrm{U}$ navedenim istraživanjima hidrogel je izravno nakon sinteze upotrijebljen bez dodatnih koraka sušenja. U slučaju kad je hidrogel liofiliziran prije primijene u superkondenzatoru, dobiveni su znatno niži kapaciteti od $19 \mathrm{Fg}^{-1} \cdot{ }^{56}$ Nedavno su Kong i sur. ${ }^{62}$ razvili 3D N- i S-kodopirani grafenski hidrogel specifične površine od $317 \mathrm{~m}^{2} \mathrm{~g}^{-1}$. Dobiven je specifični kapacitet od $320 \mathrm{~F} \mathrm{~g}^{-1}$ pri $1 \mathrm{Ag}^{-1}$. Nakon 10000 ciklusa punjenja i pražnjenja zadržano je 96,4 \% nazivnog kapaciteta, što uz navedeno ukazuje na to da je na taj način dobiven hidrogel izrazito dobrih svojstava za primjenu u superkondenzatorima. Grafenski hidrogel moguće je modificirati ako se tijekom hidrotermalne sinteze u malom postotku upotrebljavaju ispredena vlakana $\mathrm{Fe}_{2} \mathrm{O}_{3}$. Pokazano je kako prisustvo ispredenih vlakana tijekom sinteze povećava razmak između grafenskih listova i samim time povećava vrijednost specifičnih kapaciteta s $19 \mathrm{~F} \mathrm{~g}^{-1}$ na $24 \mathrm{Fg}^{-1} \cdot{ }^{56}$

\section{Materijali za pseudokondenzatore}

Komercijalno dostupni superkondenzatori uglavnom su načinjeni od ugljika kao aktivnog materijala. Specifični kapaciteti tih materijala ograničeni su na $200 \mathrm{~F} \mathrm{~g}^{-1}$ i ovise o ugljikovoj specifičnoj površini i dostupnosti pora elektrolitu. Kako bi se postigli veći specifični kapaciteti, istražuju se različiti materijali poput metalnih oksida i vodljivih polimera. ${ }^{63-65}$ Ti materijali imaju drugačiji mehanizam skladištenja naboja u odnosu na EDLC, koji uključuje redoks reakcije praćene interkalacijom/deinterkalacijom iona te površinske reakcije koje uključuju nabijanje dvosloja i elektrosorpciju iona. Tijekom odvijanja pseudokapacitivnih reakcija ne dolazi do značajnijih promjena u strukturi materijala, pa se mogu postići relativno velike brzine reakcije.

\subsection{Vodljivi polimeri}

Vodljivi polimeri predstavljaju važnu grupu elektrodnih materijala pogodnih za primjenu u superkondenzatorima zbog svoje dobre električne provodnosti i pseudokapacitivnih svojstava. Pseudokapacitivna svojstva vodljivih polimera znatno ovise o njihovoj strukturi koja definira elektronsku/ionsku vodljivost, potencijal pri kojem se odvija redoks-reakcija, stupanj oksidacije/redukcije te elektrokemijsku reverzibilnost redoks-reakcije. ${ }^{66,67}$ Najčešće upotrijebljeni vodljivi polimeri u superkondenzatorima su polianilin (PANI), polipirol (PPy) i poli(3,4-etilendioksitiofen) (PEDOT). Vodljive polimere karakteriziraju specifični kapacitet znatno veći ( 2 - 3 puta) od onih zabilježenih kod ugljikovih materijala. Osim toga, vodljive polimere moguće je upotrebljavati u savitljivim uređajima koji u današnje vrijeme privlače značajnu pozornost. Sinteziraju se kemijskim ili elektrokemijskim putem, s time da je elektrokemijska sinteza pogodnija jer se na taj način dobiva elektroda koja se može izravno upotrijebiti u superkondenzatoru. Osim toga, na taj način jednostavna je kontrola količine sintetiziranog polimera odnosno debljine sloja aktivnog materijala. Za PANI dobiven kemijskim putem specifični kapacitet iznosi $554 \mathrm{Fg}^{-1}$, dok je za polianilin dobiven elektrokemijskom polimerizacijom dobiven još veći specifični kapacitet od $742 \mathrm{Fg}^{-1}{ }^{68}$ Specifični kapaciteti PPy kreću se u rangu vrijednosti od 90 do $480 \mathrm{Fg}^{-1}$. U odnosu na ostale vodljive polimere specifični kapacitet PEDOT sloja je mnogo manji, $210 \mathrm{~F} \mathrm{~g}^{-1}$. $^{69}$ Razlog tome je velika molarna masa monomerne jedinice. No PEDOT se intenzivno istražuje kao elektrodni materijal ponajprije jer njegovi monomeri nisu toksični i zbog odlične stabilnosti kod velikog broja ciklusa te velike brzine odvijanja redoks-reakcije.

U novije vrijeme istraživanja vodljivih polimera za primjenu u superkondenzatorima usmjerena su prema sintezi kompozitnih materijala. Naime, poznato je da tijekom velikog broja ciklusa punjenja i pražnjenja dolazi do bubrenja i skupljanja polimera (uslijed stalne interkalacije i deinterkalacije iona), čime se narušava mehanička stabilnost materijala i elektrokemijske karakteristike. ${ }^{70}$ Time se znatno smanjuje broj ciklusa punjenja/pražnjenja kod superkondenzatora. Pripremom kompozita mehanička svojstva vodljivih polimera mogu se znatno poboljšati. Kompozitni materijali mogu se sintetizirati kemijskom ili elektrokemijskom metodom, slično kao i čisti vodljivi polimer. U pravilu, obje metode su jeftin i jednostavan postupak a odabir metode znatno utječe na morfologiju i kapacitivna svojstva dobivenog materijala. ${ }^{71}$

Kompoziti vodljivih polimera i grafena privlače veliku pozornost zbog toga što prisutnost grafena u strukturi vodlji- 
vog polimera može poboljšati njegova pseudokapacitivna i mehanička svojstva, što je nužno kako bi se mogle uskladištiti velike količine energije te kako bi se postigao velik broj ciklusa punjenja i pražnjenja. ${ }^{72}$ Dosadašnja istraživanja ukazuju na to da kompozite materijala na bazi grafena i vodljivih polimera kao što su PANI, PPy ili PEDOT ${ }^{73}$ karakteriziraju specifični kapaciteti od $220 \mathrm{Fg}^{-1}$ do $600 \mathrm{Fg}^{-1}$. 67,74 Dobivene vrijednosti veće su u odnosu na vrijednosti koje postiže sam grafen i vodljivi polimer. U strukturu vodljivog polimera može biti ugrađen grafen ili GO, pri čemu grafen osigurava dobru poroznost i dobru električnu provodnost dok GO osigurava samo dobru poroznost. Međutim, zbog hidrofilnog karaktera GO je znatno jednostavnije ugraditi u strukturu polimera. Također, GO je moguće iskoristiti kao osnovni elektrolit tijekom sinteze vodljivog polimera, što mu osiguravaju kisikove funkcionalne skupine koje su sklone disocijaciji poput karboksilne skupine. ${ }^{74}$ Nadalje, s ciljem poboljšavanja električne provodnosti kompozita GO/ vodljivi polimer moguće je provesti naknadnu redukciju $\mathrm{GO}$ ugrađenog $\mathrm{u}$ vodljivi polimer. ${ }^{75} \mathrm{U}$ slučaju redukcije GO u sloju PPy dobiven je specifični kapacitet $424 \mathrm{~F} \mathrm{~g}^{-1}$ koji je prije redukcije iznosio $289 \mathrm{Fg}^{-1} .^{76}$

Feng i sur. ${ }^{77}$ elektrokemijski su sintetizirali rGO/PANI kompozitni film polazeći od suspenzije GO/anilin u otopini $\mathrm{H}_{2} \mathrm{SO}_{4}$. Dobivena suspenzija nanesena je na podlogu od staklastog ugljika ili na ITO podlogu te je tako pripremljena elektroda polarizirana u području potencijala od $-1,3 \mathrm{~V}$ do $1,0 \mathrm{~V} \mathrm{u} 1 \mathrm{M} \mathrm{H}_{2} \mathrm{SO}_{4}$. Prilikom toga dolazi do polimerizacije anilina i redukcije GO u rGO. Za priređeni materijal dobiven je visok specifični kapacitet od $640 \mathrm{Fg}^{-1}$ uz $90 \%$ zadržavanje početnog kapaciteta nakon 1000 ciklusa punjenja i pražnjenja. Time je pokazano da rGO/PANI kompozit pokazuje dobru elektrokemijsku stabilnost, te je kao takav obećavajući materijal za pohranu električne energije u superkondenzatorima.

\subsection{Oksidi prijelaznih metala}

Oksidi prijelaznih metala kao što su oksidi rutenija, mangana, kobalta, nikla, željeza ili iridija intenzivno se proučavaju kao elektrodni materijali za superkondenzatore. Karakterizira ih svojstvo da imaju više oksidacijskih stanja te da se tijekom redoks-reakcija kontinuirano odvija prijelaz iz jednog oksidacijskog stanja u drugo, pri čemu se registriraju visoke struje u širokom području potencijala. Općenito, pseudokapacitivna reakcija prijelaznih metala može se prikazati navedenom jednadžbom:

$$
\mathrm{MeO}_{x}(\mathrm{OH})_{y}+\mathrm{ze}^{-}+\mathrm{zH}^{+} \leftrightarrow \mathrm{MeO}_{\mathrm{x}-\mathrm{z}}(\mathrm{OH})_{\mathrm{y}+z}
$$

Kako bi se određeni materijal mogao upotrijebiti u superkondenzatoru, nužno je da redoks-reakcija koja se odvija u materijalu pokazuje visok stupanj reverzibilnosti što osigurava velike brzine reakcije. Velike brzine reakcije mogu se postići optimiranjem elektronske i ionske električne provodnosti. Dobra elektronska provodnost osigurava se intrinzičnom vodljivošću samog oksida te dodatcima za bolju provodnost kao što je to acetilensko crnilo. Nadalje, električna provodnost može se poboljšati smanjenjem debljine sloja oksida. Dobra ionska vodljivost osigurava se hidratacijom samog materijala. Međutim, stupanj hidratacije ne smije biti visok jer može dovesti do smanjene električne provodnosti oksida. ${ }^{78}$ Isto tako, nužno je da materijal tijekom odvijanja redoks-reakcije pokazuje dobru mehaničku i kemijsku stabilnost. Najbolja svojstva postižu se kod rutenijeva oksida, jer amorfni i hiratizirani oblik $\mathrm{RuO}_{2}$ ima izvanredna pseudokapacitivna svojstva s visokim vrijednostima specifičnog kapaciteta koje idu do $720 \mathrm{Fg}^{-1} .{ }^{79}$ U slučaju kad su upotrijebljeni jako tanki filmovi $\mathrm{RuO}_{2}$, zabilježeni su kapaciteti čak do $1500 \mathrm{~F} \mathrm{~g}^{-1} .{ }^{78}$ Nedostatci $\mathrm{RuO}_{2}$ su njegova iznimno visoka cijena. U novijim istraživanjima pokušalo se prirediti kompozitne elektrode $\mathrm{s}$ manjim udjelom $\mathrm{RuO}_{2}$, a većim udjelom ugljika, ugljikovih nanocijevi, grafena, ${ }^{64,80-82}$ vodljivih polimera ${ }^{83,84}$ ili se $\mathrm{RuO}_{2}$ u potpunosti zamijenio drugim metalnim oksidima, kao što je npr. $\mathrm{MnO}_{2}$ koji je znatno jeftiniji. ${ }^{85-89}$

Pseudokapacitivna svojstva $\mathrm{MnO}_{2}$ pripisuju se redoks-reakciji $\mathrm{Mn}(\mathrm{III}) / \mathrm{Mn}(\mathrm{IV})$ koju prati izmjena protona i/ili kationa ${ }^{85,90}$ prema jedn. (8). Teoretska vrijednost specifičnog kapaciteta $\mathrm{MnO}_{2}$ dosta je velika $\left(1370 \mathrm{~F} \mathrm{~g}^{-1}\right),{ }^{91}$ što je $\mathrm{u}$ praksi teško dobiti zbog kompaktne strukture koja otežava izmjenu iona i slabe intrinzične vodljivosti. ${ }^{89,92}$ Slično kao i kod $\mathrm{RuO}_{2}$, kako bi se osigurala zadovoljavajuća pseudokapacitivna svojstva $\mathrm{MnO}_{2}$, nužno je postići dobru ionsku i elektronsku vodljivost materijala. Ionska vodljivost ovisi o tome je li materijal amorfan ili kristaličan, o veličini kristalita, kao i o samoj strukturi kristalne rešetke..$^{93}$ Nisku električnu provodnost $\mathrm{MnO}_{2}\left(10^{-4}\right.$ do $\left.10^{-6} \mathrm{~S} \mathrm{~cm}^{-1}\right)$ nastoji se povećati dodatkom vodljivih aditiva, kao što je npr. acetilensko crnilo ${ }^{89,93-95}$ ili pripravom kompozitnih elektroda načinjenih od visoko vodljivih materijala, kao što su vodljivi polimeri ${ }^{63}$ i/ili materijali na bazi ugljika. ${ }^{96}$

S obzirom na to da se tijekom redoks-reakcije odvija interkalacija iona, bitna je i kristalna struktura $\mathrm{MnO}_{2}$ (slika 7) kao i dimenzije iona koji se interkalira tijekom odvijanja redoks-reakcije. ${ }^{97}$ Utvrđeno je da se najveći kapaciteti postižu kod $\alpha-\mathrm{MnO}_{2}$ i $\delta-\mathrm{MnO}_{2}$ kao posljedica širih kanala i većih udaljenosti među ravninama u kristalnoj rešetci.

Pripravom kompozitnih materijala $\mathrm{MnO}_{2}$ i vodljivih polimera kao što su PPy ${ }^{98-100,63}$ i politiofen ${ }^{101,102}$ omoguće-

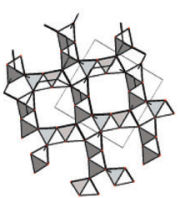

$(\alpha)$

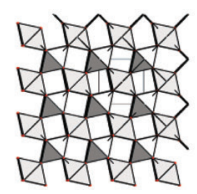

$(\beta)$

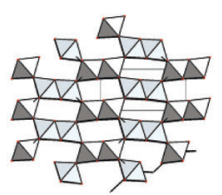

$(\gamma)$

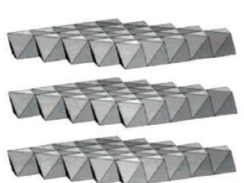

(ठ)

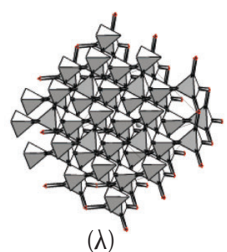

$(\lambda)$

Slika 7 - Različite kristalne strukture $\mathrm{MnO}_{2}{ }^{97}$

Fig. 7 - Different crystalline structures of $\mathrm{MnO}_{2}{ }^{97}$ 
na je fina disperzija $\mathrm{MnO}_{2}$ i zbog toga bolja iskoristivost materijala. Nedostatak tih kompozita je slaba mehanička i elektrokemijska stabilnosti, stoga se sintetiziraju kompoziti $\mathrm{MnO}_{2}$ i materijala na bazi ugljika koji mogu osigurati i bolju mehaničku stabilnost. ${ }^{101-104}$ Zhao i sur. ${ }^{105}$ sintetizirali su kompozit $\mathrm{MnO}_{x} / \mathrm{CNT}$ katodonom elektrodepozicijom $\mathrm{MnO}_{x}$ iz $\mathrm{KMnO}_{4}$ otopine na površinu ugljikovih nanocijevi koje su prethodno rasle na $\mathrm{Ti} / \mathrm{Si}$ supstratu. $\mathrm{U}$ navedenom radu dobiven je specifični kapacitet od $400 \mathrm{~F} \mathrm{~g}^{-1}$ za masu $\mathrm{MnO}_{\mathrm{x}}$ od $50 \mu \mathrm{gcm}^{-2}$ pri gustoći struje od $10 \mathrm{Ag}^{-1}$. U istom radu također je uočeno da se daljnjim povećanjem mase $\mathrm{MnO}_{x}$ dobivaju niži kapaciteti. Ko $i$ sur. ${ }^{106}$ ukazali su na važnost aktivacije ugljikovih nanocijevi kemijskim tretmanom u KOH otopini pri $800{ }^{\circ} \mathrm{C}$ prije same sinteze $\mathrm{MnO}_{2}$. Specifični kapacitet za neaktivirani $\mathrm{MnO}_{2} / \mathrm{CNT}$ kompozit iznosio je $215 \mathrm{~F} \mathrm{~g}^{-1}$, dok za aktivirani $250 \mathrm{Fg}^{-1}$. U drugom radu je pokazano da kao pogodna podloga za sintezu $\mathrm{MnO}_{2}$ mogu poslužiti ugljikove nanocijevi polarizirane $u$ području pozitivnih potencijala. U slučaju sinteze na tim nanocijevima dobiveni su znatno veći kapaciteti. Polarizacijom su uvedene dodatne funkcionalne skupine koje povećavaju hidrofilnost nanocijevi i time utječu na brzinu sinteze, strukturu $\mathrm{MnO}_{2}$ te na vrijednosti specifičnih kapaciteta. Tako je u otopini $\mathrm{MnCl}_{2}$ za elektrodu aktivirane nanocijevi/ $\mathrm{MnO}_{2}$ postignut kapacitet od $262 \mathrm{~F} \mathrm{~g}^{-1}$, dok je za elektrodu nanocijevi/ $/ \mathrm{MnO}_{2}$ postignut kapacitet $216 \mathrm{~F} \mathrm{~g}^{-1}$. $\mathrm{Za}$ usporedbu je navedeno da $\mathrm{MnO}_{2}$ sintetiziran na podlozi od Pt pokazuje kapacitet od $151 \mathrm{~F} \mathrm{~g}^{-1} \cdot{ }^{9}$ Liu $i$ sur. ${ }^{107}$ sintetizirali su $\mathrm{MnO}_{2}$ /grafen kompozit hidrotermalnom metodom. Elektrokemijska mjerenja pokazala su da kompozitna elektroda pokazuje specifični kapacitet od $315 \mathrm{~F} \mathrm{~g}^{-1}$ pri 0,2 $\mathrm{Ag}^{-1}$ što je veće u odnosu na elektrodu načinjenu samo od grafena ili samo od $\mathrm{MnO}_{2}$. Također, nakon 2000 ciklusa 87 \% početnog kapaciteta se zadržava. Zbog dobivene jedinstvena strukture kompozita koja se razlikuje od strukture čistog $\mathrm{MnO}_{2}$ osigurana je dobra vodljivost i brza izmjena iona i elektrona.

Materijal koji se razmatra za upotrebu u superkondenzatorima i koji ne spada u grupu oksida prijelaznih metala je $\mathrm{SnO}_{2}$. Kod njega se dobivaju niži kapaciteti108, međutim i dalje se intenzivno istražuje iz razloga što je jeftin, lako dostupan i ekološki prihvatljiv. Kao i u slučaju s $\mathrm{MnO}_{2}$ glavni problemi $\mathrm{SnO}_{2}$ su slaba električna provodnost i loša mehanička stabilnost. Ti nedostatci se pokušavaju riješiti sintezom kompozitnih materijala s grafenom, ${ }^{80,81,109}$ ugljikom ${ }^{111-114}$ ili drugim metalnim oksidima. ${ }^{115,116}$

\section{Zaključak}

Za dobru izvedbu superkondenzatora ključnu ulogu ima odabir pogodnog elektrodnog materijala. O njemu će ovisiti količina pohranjenog električnog naboja, ali i brzina skladištenja, što znači da vrsta materijala definira specifične vrijednosti energije i snage. Do sada su u komercijalno dostupnim uređajima elektrode uglavnom bile pripravljene od materijala na bazi aktivnog ugljika, a danas se intenzivno istražuju i drugi ugljikovi materijali poput grafena. Odlika tih materijala je velika specifična površina i poroznost, no unatoč tome specifični kapaciteti $\left(200 \mathrm{~F} \mathrm{~g}^{-1}\right)$ i gustoća energije $\left(5-10 \mathrm{Wh} \mathrm{kg}^{-1}\right)$ koji se postižu su relativ- no niski. Stoga se sve više istražuju i primjenjuju pseudokapacitivni materijali poput vodljivih polimera i metalnih oksida. Oni pokazuju slična elektrokemijska svojstva koja se dobivaju kod aktivnog ugljika, ali znatno veći specifični kapaciteti $\left(700 \mathrm{~F} \mathrm{~g}^{-1}\right.$ ). Za obje vrste navedenih materijala karakteristično je da je proces skladištenja naboja brz, što doprinosi visokoj specifičnoj snazi $\left(5-100 \mathrm{~kW} \mathrm{~kg}^{-1}\right)$. Isto tako, karakterizira ih relativno dobra kemijska i mehanička stabilnost što osigurava više stotina tisuća ciklusa punjenja/ pražnjenja bez značajne promjene svojstava elektrodnog materijala. Bitno je napomenuti da nešto lošiju stabilnost pokazuju pseudokapacitivni materijali, pa se njihova svojstva pokušavaju poboljšati na način da se priređuju kompozitni materijali. Dodatno, novija istraživanja usmjerena su prema hibridnim uređajima koji kombiniraju ugljikove elektrode i elektrode s pseudokapacitivnim svojstvima te hibridnim uređajima koji kombiniraju elektrode tipične za superkondenzatore i elektrode karakteristične za baterije. U takvim uređajima, pažljivim odabirom ne samo elektrodnog materijala nego i elektrolita koji određuje radni napon, može se zadržati velika specifična snaga karakteristična za superkondenzatore te postići specifična energije koja je znatno veća u odnosu na dosadašnje vrijednosti $\left(6,8 \mathrm{Wh} \mathrm{kg}^{-1}\right.$ i $\left.110 \mathrm{~kW} \mathrm{~kg}^{-1}\right)$.

\section{ZAHVALA}

Istraživanja vezana uz aktivne materijale za superkondenzatore provedena su na Zavodu za elektrokemiju (FKIT) u sklopu projekta "Elektrokemijski superkondenzator velike snage $i$ velike energije za hibridna električna vozila" IP2013-11-8825 financiranom od strane Nacionalne zaklade za znanost, visoko školstvo i tehnologijski razvoj RH.

\section{Popis kratica i simbola}

\section{List of abbreviations and symbols}

\begin{tabular}{|c|c|}
\hline$A$ & $\begin{array}{l}\text { - aktivna površina, } \mathrm{m}^{2} \\
\text { - active surface area, } \mathrm{m}^{2}\end{array}$ \\
\hline$C$ & $\begin{array}{l}\text { - kapacitet, F } \\
\text { - capacitance, F }\end{array}$ \\
\hline Cs & $\begin{array}{l}\text { - specifični kapacitet, } \mathrm{Fg}^{-1} \\
\text { - specific capacitance, } \mathrm{Fg}^{-1}\end{array}$ \\
\hline$d$ & $\begin{array}{l}\text { - udaljenost između elektroda, m } \\
\text { - distance between the electrodes, m }\end{array}$ \\
\hline$P_{\mathrm{s}}$ & $\begin{array}{l}\text { - specifična snaga, } \mathrm{Wg}^{-1} \\
\text { - specific power, } \mathrm{Wg}^{-1}\end{array}$ \\
\hline$P_{\mathrm{m}}$ & $\begin{array}{l}\text { - maksimalna snaga, } \mathrm{W} \\
\text { - maximum power, } \mathrm{W}\end{array}$ \\
\hline$W_{\mathrm{s}}$ & $\begin{array}{l}\text { - specifična energija, Wh } \mathrm{g}^{-1} \\
\text { - specific energy, Wh g }\end{array}$ \\
\hline$\varepsilon_{0}$ & $\begin{array}{l}\text { - dielektrična permitivnost vakuuma, } \mathrm{F} \mathrm{m}^{-1} \\
\text { - vacuum permittivity, } \mathrm{F} \mathrm{m}^{-1}\end{array}$ \\
\hline$\varepsilon$ & $\begin{array}{l}\text { - dielektrična permitivnost } \\
\text { - dielectric permittivity }\end{array}$ \\
\hline$U$ & $\begin{array}{l}\text { - napon, V } \\
\text { - voltage, V }\end{array}$ \\
\hline
\end{tabular}




\begin{tabular}{|c|c|}
\hline$Q$ & $\begin{array}{l}\text { - naboj, C } \\
\text { - charge, C }\end{array}$ \\
\hline$R$ & $\begin{array}{l}\text { - ekvivalentni serijski otpor, } \Omega \\
\text { - equivalent series resistance, } \Omega\end{array}$ \\
\hline CNT & $\begin{array}{l}\text { - ugljikove nanocijevi } \\
\text { - carbon nanotubes }\end{array}$ \\
\hline GO & $\begin{array}{l}\text { - grafenov oksid } \\
\text { - graphene oxide }\end{array}$ \\
\hline rGO & $\begin{array}{l}\text { - reducirani grafenov oksid } \\
\text { - reduced graphene oxide }\end{array}$ \\
\hline EDLC & $\begin{array}{l}\text { - elektrokemijski dvoslojni kondenzatori } \\
\text { - electrochemical double layer capacitors }\end{array}$ \\
\hline PANI & $\begin{array}{l}\text { - polianilin } \\
\text { - polyanilin }\end{array}$ \\
\hline PPy & $\begin{array}{l}\text { - polipirol } \\
\text { - polypyrole }\end{array}$ \\
\hline PEDOT & $\begin{array}{l}\text { - poli(3,4-etilendioksitiofen) } \\
\text { - poly(3,4-ethylenedioxythiophene) }\end{array}$ \\
\hline
\end{tabular}

\section{Literatura}

\section{References}

1. Z. Lin, E. Goikolea, A. Balducci, K. Naoi, P. L. Taberna, M. Salanne, G. Yushin, P. Simon, Materials for supercapacitors: when Li-ion battery power is not enough, Mater. Today 21 (2018) 419-436, doi: https://doi.org/10.1016/j.mattod.2018.01.035.

2. P. Kurzweil, Electrochemical capacitors, u C. K. Dyer, P. T. Moseley, Z. Ogumi, D. A. J. Rand, B. Scrosati J. Garche (ur.), Encyclopedia of electrochemical power sources, Vol. 1, Elsevier, 2009., str. 607-633 (Electrochemical Double-Layer Capacitors), str. 634-648 (Electrochemical Double-Layer Capacitors: Carbon Materials), str. 665-678 (Electrochemical Metal Oxides Capacitors Electrochemical encyclopedia), str. 679-684 (Electrochemical Polymer Capacitors), doi: https:// doi.org/10.1016/B978-044452745-5.00352-X.

3. B. E. Conway, Electrochemical Supercapacitors: Scientific Fundamentals and Technological Applications, Springer, 1999.

4. A. Muzaffar, M. B. Ahameda, K. Deshmukh, J. Thirumalai, A review on recent advances in hybrid supercapacitors: design, fabrication and applications, Renew. Sust. Energ. Rev. 101 (2019) 123-145, doi: https://doi.org/10.1016/j. rser.2018.10.026.

5. J. R. Miller, Electrochemical capacitors, u C. K. Dyer, P. T. Moseley, Z. Ogumi, D. A. J. Rand, B. Scrosati J. Garche (ur.), Encyclopedia of electrochemical power sources, Vol. 1, Elsevier, 2009., str. 587-599.

6. Maxwel technologies, Enabling energy future, ultra-capacitors, state of art and future trends, 2017.

7. J. Garche, C. K. Dyer, Encyclopedia of Electrochemical Power Sources, Amsterdam; Boston: Academic Press: Imprint of Elsevier, 2009, Capacitor Basics, str. 587-599.

8. P. Sharma, T. S. Bhatti, A review on electrochemical double-layer capacitors, Energy Convers. Manag. 51 (2010) 2901-2912, doi: https://doi.org/10.1016/j.enconman.2010.06.031.

9. A. Schneuwly, R. Gallay, Properties and applications of supercapacitors, from the state-of-the-art to future trends, Proceeding PCIM 2000 (2000) 1-10.

10. H. I. Becker, "United States Patent Office," 195.
11. A. G. Pandolfo, A. F. Hollenkamp, Carbon properties and their role in supercapacitors, J. Power Sources 157 (2006) 11-27, doi: https://doi.org/10.1016/j.jpowsour.2006.02.065.

12. S. Chen, L. Ma, K. Zhang, M. Kamruzzaman, C. Zhi, J. A. Zapien, A flexible solid-state zinc ion hybrid supercapacitor based on co-polymer derived hollow carbon spheres, J. Mater. Chem. A 7 (2019) 7784-7790, doi: https://doi. org/10.1039/C9TA00733D.

13. Y. Yuan, C. Wang, K. Lei, H. Li, F. Li, J. Chen, Sodium-ion hybrid capacitor of high power and energy density, ACS Cent. Sci. 4 (2018) 1261-1265, doi: https://doi.org/10.1021/ acscentsci.8b00437.

14. URL: https://licaptech.com/lithium-ion-capacitors (5. 6. 2019.).

15. URL:https://www.thomasnet.com/articles/top-suppliers/capacitor-manufacturers-suppliers/ (3. 6. 2019.)

16. E. Frackowiak, F. Beguin, Carbon materials for the electrochemical storage of energy in capacitors, J. Carbon 39 (2001) 937-950, doi: https://doi.org/10.1016/S00086223(00)00183-4.

17. P. Liu, M. Verbrugge, S. Soukiazian, Influence of temperature and electrolyte on the performance of activated-carbon supercapacitors, J. Power Sources 156 (2006) 712-718, doi: https://doi.org/10.1016/j.jpowsour.2005.05.055.

18. A. Hofmann, M. Schulz, T. Hanemann, Effect of conducting salts in ionic liquid based electrolytes: viscosity, conductivity, and Li-lon cell studies, Int. J. Electrochem. Sci. 8 (2013) 10170-10189.

19. A. Eftekhari, Supercapacitors utilising ionic liquids, Energy Storage Mater. 9 (2017) 47-69, doi: https://doi. org/10.1016/j.ensm.2017.06.009.

20. S. Sopčić, D. Antonić, Z. Mandić, K. Kvastek, V. Horvat-Radošević, Single and multi-frequency impedance characterization of symmetric activated carbon single capacitor cells, J. Electrochem. Sci. Eng. 8 (2018) 183-195, doi: https://doi. org/10.5599/jese.536

21. K. Kim, J. An, K. Park, G. Roh, K. Chun, Analysis of a supercapacitor/battery hybrid power system for a bulk carrier, Appl. Sci. 9 (2019) 1547, doi: https://doi.org/10.3390/ app9081547.

22. S. Konwer, R. Boruah, S. K. Dolui, Studies on conducting polypyrrole/graphene oxide composites as supercapacitor electrode, J. Electron. Mater. 40 (2011) 2248-2255, doi: https://doi.org/10.1007/s11664-011-1749-z.

23. M. Y. Ho, P. S. Khiew, D. Isa, T. K. Tan, W. S. Chiu, C. H. Chia, A review of metal oxide composite electrode materials for electrochemical capacitors, Nano: Brief Reports Rev. 9 (2014) 1430001-1430025, doi: https://doi.org/10.1142/ S1793292014300023.

24. D. Belanger, T. Brousse, J. W. Long, Manganese oxides: battery materials make the leap to electrochemical capacitors, Electrochem. Soc. Interface 17 (2008) 49-52.

25. P. Gao, A. Lu, W. Li, Dual functions of activated carbon in a positive electrode for $\mathrm{MnO}_{2}$-based hybrid supercapacitor, J. Power Sources 196 (2011) 4095-4101, doi: https://doi. org/10.1016/j.jpowsour.2010.12.056.

26. D. Zhao, Y. Zhao, X. Zhang, C. Xu, Y. Peng, H. Li, Z. Yang, Application of high-performance $\mathrm{MnO}_{2}$ nanocomposite electrodes in ionic liquid hybrid supercapacitors, Mater. Lett. 107 (2013) 115-118, doi: https://doi.org/10.1016/j. matlet.2013.05.053.

27. T. Brousse, D. Bélangere, J. W. Long, To be or not to be pseudocapacitive?, J. Electrochem. Soc. 162 (2015) A5185A5189, doi: https://doi.org/10.1149/2.0201505jes.

28. I. Varakin, A. Stepanov, V. Menukhov, Pat. WO97/07518, US 
patent 5,986,876 "Capacitor with a double electrical layer", 14 August, 1995.

29. H. Wang, M. Wang, Y. Tang, A novel zinc-ion hybrid supercapacitor for long-life and low-cost energy storage applications, Energy Storage Mater. 13 (2018) 1-7, doi: https://doi. org/10.1016/j.ensm.2017.12.022.

30. G. G. Amatucci, F. Badway, A. Du Pasquier, T. Zheng, An asymmetric hybrid nonaqueous energy storage cell, J. Electrochem. Soc. 148 (2001) A930-A939, doi: https://doi. org/10.1149/1.1383553.

31. J. Kang, J. Wen, S. H. Jayaram, X. Wang, S. K. Chen, Electrochemical characterization and equivalent circuit modeling of single-walled carbon nanotube (SWCNT) coated electrodes, J. Power Sources 234 (2013) 208-216, doi: https:// doi.org/10.1016/j.jpowsour.2013.01.058.

32. P. Simon, Y. Gogotsi, Materials for electrochemical capacitors, Nat. Mater. 7 (2008) 845-854, doi: https://doi.org/10.1038/ nmat2297.

33. K. Jurewicz, C. Vix-Guterl, E. Frackowiak, S. Saadallah, M. Reda, J. Parmentier, J. Patarin, F. Béguin, Capacitance properties of ordered porous carbon materials prepared by a templating procedure, J. Phys. Chem. Solids 65 (2004) 287-293, doi: https://doi.org/10.1016/j.jpcs.2003.10.023.

34. I. Inala, S. Holmes, E. Yagmura, N. Ermumcu, A. Banford, Z. Aktas, The supercapacitor performance of hierarchical porous activated carbon electrodes synthesised from demineralised (waste) cumin plant by microwave pretreatment, J. Ind. Eng. Chem. 61 (2018) 124-132, doi: https://doi. org/10.1016/j.jiec.2017.12.009.

35. X. Zhu, S. Yu, K. Xu, Y. Zhang, L. Zhang, G. Lou, Y. Wu, E. Zhu, H. Chen, Z. Shen, B. Bao, S. Fu, Sustainable activated carbons from dead ginkgo leaves for supercapacitor electrode active materials, Chem. Eng. Sci. 181 (2018) 36-45, doi: https:// doi.org/10.1016/j.ces.2018.02.004.

36. K. S. Novoselov, A. K. Geim, S. V Morozov, D. Jiang, Electric field effect in atomically thin carbon films, Science 306 (2004) 666-669, doi: https://doi.org/10.1126/science. 1102896

37. C. T. J. Low, F. C. Walsha, M. H. Chakrabarti, M. A. Hashim, M. A. Hussain, Electrochemical approaches to the production of graphene flakes and their potential applications, Carbon 54 (2012) 1-21, doi: https://doi.org/10.1016/j.carbon.2012.11.030.

38. P. Yu, S. E. Lowe, G. P. Simon, Y. L. Zhong, Electrochemical exfoliation of graphite and production of functional graphene, Curr. Opin. Colloid Interface Sci. 20 (2015) 329-338, doi: https://doi.org/10.1016/j.cocis.2015.10.007.

39. A. Ambrosi, C. K. Chua, A. Bonanni, M. Pumera, Electrochemistry of graphene and related materials, Chem. Rev. 114 (2014) 7150-7188, doi: https://doi.org/10.1021/cr500023c.

40. D. R. Dreyer, S. Park, W. Bielawski, R. S. Ruoff, The chemistry of graphene oxide, Chem. Soc. Rev. 39 (2010) 228-240, doi. https://doi.org/10.1039/B917103G.

41. Q. Chi, Approaching the theoretical capacitance of graphene through copper foam integrated three-dimensional graphene networks, J. Mater. Chem. A 3 (2015) 6324-6329, doi: https://doi.org/10.1039/C5TA01112D.

42. S. Pei, H. Cheng, The reduction of graphene oxide, Carbon 50 (2011) 3210-3228, doi: https://doi.org/10.1016/j.carbon.2011.11.010.

43. S. Y. Toha, K. S. Loha, S. K. Kamarudin, W. R. W. Dauda, Graphene production via electrochemical reduction of graphene oxide: Synthesis and characterisation, Chem. Eng. J. 251 (2014) 422-434, doi: https://doi.org/10.1016/j. cej.2014.04.004.
44. Z. Yang, Q. Zheng, H. Qiu, J. Li, J. Yang, A simple method for the reduction of graphene oxide by sodium borohydride with $\mathrm{CaCl}_{2}$ as a catalyst, New Carbon Mater. 30 (2015) 4147, doi: https://doi.org/10.1016/S1872-5805(15)60174-3.

45. K. Kanishka, H. De Silva, H. Huang, M. Yoshimura, Progress of reduction of graphene oxide by ascorbic acid, Appl. Surf. Sci. 447 (2018) 338-346, doi: https://doi.org/10.1016/j.apsusc.2018.03.243.

46. S. R. C. Vivekchand, C. S. Rout, K. S. Subrahmanyam, A. Govindaraj, C. N. R. Rao, Graphene-based electrochemical supercapacitors, J. Chem. Sci.120 (2008) 9-13, doi: https:// doi.org/10.1007/s12039-008-0002-7.

47. Y. Wang, Z. Shi, Y. Huang, Y. Ma, C. Wang, M. Chen, Y. Chen, supercapacitor devices based on graphene materials, J. Phys. Chem. C 113 (2009) 13103-13107, doi: https://doi. org/10.1021/jp902214f.

48. H. Feng, R. Cheng, X. Zhao, X. Duan, J. Li, A low-temperature method to produce highly reduced graphene oxide, Nat. Commun. 4 (2013) 1539, doi: https://doi.org/10.1038/ ncomms2555.

49. Y. Zhu, S. Murali, M. D. Stoller, A. Velamakanni, R. D. Piner, R. S. Ruoff, Microwave assisted exfoliation and reduction of graphite oxide for ultracapacitors, Carbon 48 (2010) 2118 2122, doi: https://doi.org/10.1016/j.carbon.2010.02.001.

50. K. Zhang, L. Mao, L. Li. Zhang, H. Chan, X. S. Zhaob, J. Wu, Surfactant-intercalated, chemically reduced graphene oxide for high performance supercapacitor electrodes, J. Mater. Chem. 21 (2011) 7302-7307, doi: https://doi.org/10.1039/ c1jm00007a.

51. G. Wang, X. Sun, F. Lu, H. Sun, M. Yu, W. Jiang, C. Liu, J. Lian, Flexible pillared graphene-paper electrodes for high-performance electrochemical supercapacitors, Small 8 (2012) 452-459, doi: https://doi.org/10.1002/smll.201101719.

52. J. Yan, T. Wei, B. Shao, F. Ma, Z. Fan, M. Zhang, C. Zheng, Y. Shang, W. Qian, F. Wei, Electrochemical properties of graphene nanosheet/carbon black composites as electrodes for supercapacitors, Carbon 48 (2010) 1731-1737, doi: https://doi.org/10.1016/j.carbon.2010.01.014.

53. L. Qiu, X. Yang, X. Gou, W. Yang, Z. Ma, Dispersing carbon nanotubes with graphene oxide in water and synergistic effects between graphene derivatives, Chem. Eur. J. 16 (2010) 10653-10658, doi: https://doi.org/10.1002/ chem. 201001771.

54. Z. Fan, J. Yan, L. Zhi, Q. Zhang, T. Wei, J. Feng, M. Zhang, W. Qian, F. Wei, A three-dimensional carbon nanotube/ graphene sandwich and its application as electrode in supercapacitors, Adv. Mater. 22 (2010) 3723-3728, doi: https:// doi.org/10.1002/adma.201001029.

55. Y. Si, E. T. Samulski, Exfoliated graphene separated by platinum nanoparticles, Chem. Mater. 20 (2008) 6792-6797, doi: https://doi.org/10.1021/cm801356a.

56. G. Radić, I. Šajnović, T. Petrović, M. Kraljić Roković, Reduced graphene oxide/a- $\mathrm{Fe}_{2} \mathrm{O}_{3}$ fibers as active material for supercapacitor application, Croat. Chem. Acta 91 (2018) 15231534, doi: https://doi.org/10.5562/cca3452.

57. K. Hu, X. Xie, T. Szkopek, M. Cerruti, Understanding hydrothermally reduced graphene oxide hydrogels: from reaction products to hydrogel properties, Chem. Mater. 28 (2016) 1756-1768, doi: https://doi.org/10.1021/acs.chemmater.5b04713.

58. S. P. Sasikala, P. Poulin, C. Aymonier, Advances in subcritical hydro-/solvothermal processing of graphene materials, Adv. Mater. 29 (2017) 1605473, doi: https://doi.org/10.1002/ adma.201605473.

59. Y. Xu, K. Sheng, C. Li, G. Shi, Self-assembled graphene hydro- 
gel via a one-step hydrothermal process, ACS Nano 4 (2010) 4324-4330, doi: https://doi.org/10.1021/nn101187z.

60. L. Zhang, G. Shi, Preparation of highly conductive graphene hydrogels for fabricating supercapacitors with high rate capability, J. Phys. Chem. C 115 (2011) 17206-17212, doi: https://doi.org/10.1021/jp204036a.

61. D. Sačer, Doktorski rad, Sveučilište u Zagrebu, 2018.

62. W. Kong, J. Zhu, M. Zhang, Y. Liu, J. Hu, Three-dimensional $\mathrm{N}$ - and $\mathrm{S}$-codoped graphene hydrogel with in-plane pores for high performance supercapacitor, Micropor. Mesopor. Mater. 268 (2018) 260-267, doi: https://doi.org/10.1016/j. micromeso.2018.04.029.

63. N. Šešelj, D. Sačer, M. Kraljić Roković, Karakterizacija pseudokapacitivnih svojstava kemijski priređenog $\mathrm{MnO}_{2}$ te kompozita $\mathrm{MnO}_{2} /$ polipirol, Kem. Ind. 65 (2016) 127-136, doi: https://doi.org/10.15255/KUI.2015.009.

64. C. D. Lokhande, D. P. Dubal, O. Joo, Metal oxide thin film based supercapacitors, Curr. Appl. Phys. 11 (2011) 255270, doi: https://doi.org/10.1016/j.cap.2010.12.001.

65. L. Coustan, A. Le Comte, T. Brousse, F. Favier, $\mathrm{MnO}_{2}$ as ink material for the fabrication of supercapacitor electrodes, Electrochim. Acta 152 (2015) 520-529, doi: https://doi. org/10.1016/j.electacta.2014.11.010.

66. S. Bose, T. Kuila, E. Uddin, N. Hoon, A. K. T. Lau, J. Hee, In-situ synthesis and characterization of electrically conductive polypyrrole/graphene nanocomposites, Polymer 51 (2010) 5921-5928, doi: https://doi.org/10.1016/j.polymer.2010.10.014

67. K. Qi, Y. Qiu, X. Guo, Pulse electrochemical incorporation of graphene oxide into polypyrrole films for supercapacitor electrode materials, Electrochim. Acta 137 (2014) 685-692, doi: https://doi.org/10.1016/j.electacta.2014.06.083.

68. H. Li, J. Wang, Q. Chu, Z. Wang, F. Zhang, S. Wang, Theoretical and experimental specific capacitance of polyaniline in sulfuric acid, J. Power Sources 190 (2009) 578-586, doi: https://doi.org/10.1016/j.jpowsour.2009.01.052.

69. G. A. Snook, C. Peng, D. J. Fray, G. Z. Chen, Achieving high electrode specific capacitance with materials of low mass specific capacitance: Potentiostatically grown thick micro-nanoporous PEDOT films, Electrochem. Commun. 9 (2007) 83-88, doi: https://doi.org/10.1016/j.elecom.2006.08.037.

70. C. Peng, S. Zhang, D. Jewell, G. Z. Chen, Carbon nanotube and conducting polymer composites for supercapacitors, Pro. Nat. Sci.18 (2008) 777-788, doi: https://doi. org/10.1016/j.pnsc.2008.03.002.

71. Y. Liu, H. Wang, J. Zhou, L. Bian, E. Zhu, J. Hai, Graphene/ polypyrrole intercalating nanocomposites as supercapacitors electrode, Electrochim. Acta 112 (2013) 44-52, doi: https:// doi.org/10.1016/j.electacta.2013.08.149.

72. L. L. Zhang, S. Zhao, X. N. Tian, X. S. Zhao, Layered graphene oxide nanostructures with sandwiched conducting polymers as supercapacitor electrodes, Langmuir 26 (2010) 1762417628, doi: https://doi.org/10.1021/la103413s.

73. J. Zhang, X. S. Zhao, Conducting polymers directly coated on reduced graphene oxide sheets as high-performance supercapacitor electrodes, J. Phys. Chem. C 116 (2012) 54205426, doi: https://doi.org/10.1021/jp211474e.

74. D. Sačer, D. Čapeta, I. Š. Rakić, R. Peter, M. Petravić, M. Kraljić Roković, Tailoring polypyrrole supercapacitive properties by intercalation of graphene oxide within the layer, Electrochim. Acta 193 (2016) 311-320, doi: https://doi. org/10.1016/j.electacta.2016.02.055.

75. S. Lehtimaki, M. Suominen, P. Damlin, S. Tuukkanen, C. Kvarnstrom, D. Lupo, Preparation of supercapacitors on flexible substrates with electrodeposited PEDOT/graphene compos- ites, ACS Appl. Mater. Interf. 7 (2015) 22137-22147, doi: https://doi.org/10.1021/acsami.5b05937.

76. H. Chang, C. Chang, Y. Tsai, Electrochemically synthesized graphene/polypyrrole composites and their use in supercapacitor, Carbon 50 (2012) 2331-2336, doi: https://doi. org/10.1016/j.carbon.2012.01.056.

77. X. Feng, R. Li, Y. Ma, R. Chen, N. Shi, Q. Fan, One-step electrochemical synthesis of graphene/polyaniline composite film and its applications, Adv. Funct. Mater. 21 (2011) 29892996, doi: https://doi.org/10.1002/adfm.201100038.

78. S. Sopčić, Z. Mandić, G. Inzelt, M. Kraljić Roković, E. Meštrović, Ion dynamics in the pseudocapacitive reaction of hydrous ruthenium oxide. Effect of the temperature pre-treatment, J. Power Sources 196 (2011) 4849-4858, doi: https:// doi.org/10.1016/j.jpowsour.2011.01.070.

79. I. Kim, K. Kim, Electrochemical characterization of hydrous ruthenium oxide thin-film electrodes for electrochemical capacitor, J. Electrochem. Soc. 153 (2006) A383-A389, doi: https://doi.org/10.1149/1.2147406.

80. D. Sačer, M. Kralj, S. Sopčić, M. Košević, A. Dekanski, M. Kraljić Roković, Supercapacitors based on graphene/pseudocapacitive materials, J. Serb. Chem. Soc. 82 (2017) 411-416, doi: https://doi.org/10.2298/JSC170207027S.

81. V. Velmurugan, U. Srinivasarao, R. Ramachandran, M. Saranya, C. Santhosh, A. N. Grace, Synthesis of tin oxide/ graphene $\left(\mathrm{SnO}_{2} / \mathrm{G}\right)$ nanocomposite and its electrochemical properties for supercapacitor applications, Mater. Res. Bull. 84 (2016) 145-151, doi: https://doi.org/10.1016/j.materresbull.2016.07.015.

82. V. V. Panić, A. B. Dekanski, R. M. Stevanovi, Sol-gel processed thin-layer ruthenium oxide/carbon black supercapacitors: a revelation of the energy storage issues, J. Power Sources 195 (2010) 3969-3976, doi: https://doi.org/10.1016/j.jpowsour.2010.01.028

83. S. Sopčić, M. Kraljić Roković, Z. Mandić, G. Inzelt, Preparation and characterization of $\mathrm{RuO}_{2} /$ polyaniline composite electrodes, J. Solid State Electrochem. 14 (2010) 20212026, doi: https://doi.org/10.1007/s10008-010-1042-8.

84. S. Sopčić, M. Kraljić Roković, Z. Mandić, Preparation and characterization of $\mathrm{RuO}_{2} /$ polyaniline/polymer binder composite electrodes for supercapacitor applications, J. Electrochem. Sci. Eng. 2 (2012) 41-52, doi: https://doi. org/10.5599/jese.2012.0010.

85. M. Toupin, T. Brousse, D. Be, Influence of microstructure on the charge storage properties of chemically synthesized manganese dioxide, Chem. Mater. 14 (2002) 3946-3952, doi: https://doi.org/10.1021/cm020408q.

86. P. K. Nayak, N. Munichandraiah, Simultaneous electrodeposition of $\mathrm{MnO}_{2}$ and $\mathrm{Mn}(\mathrm{OH})_{2}$ for supercapacitor studies, Electrochem. Solid-State Lett. 12 (2009) A115-A119, doi: https://doi.org/10.1149/1.3110010.

87. C. Hu, T. Tsou, Ideal capacitive behavior of hydrous manganese oxide prepared by anodic deposition, Electrochem. Commun. 4 (2002) 105-109, doi: https://doi.org/10.1016/ S1388-2481(01)00285-5.

88. Y. U. Jeong, A. Manthiram, Nanocrystalline manganese oxides for electrochemical capacitors with neutral electrolytes, J. Electrochem. Soc. 149 (2002) A1419-A1422, doi: https:// doi.org/10.1149/1.1511188.

89. S. Devaraj, N. Munichandraiah, Effect of crystallographic structure of $\mathrm{MnO}_{2}$ on its electrochemical capacitance properties, J. Phys. Chem. C 112 (2008) 4406-4417, doi: https:// doi.org/10.1021/jp7108785.

90. J. Wei, N. Nagarajan, I. Zhitomirsky, Manganese oxide films for electrochemical supercapacitors, J. Mater. Process. Tech- 
nol. 186 (2007) 356-361, doi: https://doi.org/10.1016/j. jmatprotec.2007.01.003.

91. S. R. Sivakkumar, J. Myoun, D. Young, B. C. Kim, G. G. Wallace, Performance evaluation of CNT/polypyrrole $\mathrm{MnO}_{2}$ composite electrodes for electrochemical capacitors, Electrochim. Acta 52 (2007) 7377-7385, doi: https://doi. org/10.1016/j.electacta.2007.06.023.

92. C. Hu, T. Tsou, Capacitive and textural characteristics of hydrous manganese oxide prepared by anodic deposition, Electrochim. Acta 47 (2002) 3523-3532, doi: https://doi. org/10.1016/S0013-4686(02)00321-3.

93. T. Brousse, M. Toupin, R. Dugas, L. Athouël, O. Crosnier, D. Bélanger, Crystalline $\mathrm{MnO}_{2}$ as possible alternatives to amorphous compounds in electrochemical supercapacitors, J. Electrochem. Soc. 153 (2006) A2171-A2180, doi: https:// doi.org/10.1149/1.2352197.

94. T. Brousse, P. Taberna, O. Crosnier, R. Dugas, P. Guillemet, Y. Scudeller, Y. Zhou, B. Daniel, P. Simon, Long-term cycling behavior of asymmetric activated carbon/ $\mathrm{MnO}_{2}$ aqueous electrochemical supercapacitor, J. Power Sources 173 (2007) 633-641, doi: https://doi.org/10.1016/j.jpowsour.2007.04.074.

95. P. Staiti, F. Lufrano, Investigation of polymer electrolyte hybrid supercapacitor based on manganese oxide - carbon electrodes, Electrochim. Acta 55 (2010) 7436-7442, doi: https://doi.org/10.1016/j.electacta.2010.01.021.

96. S. Sopčić, N. Šešelj, M. Kraljić Roković, Influence of supporting electrolyte on the pseudocapacitive properties of $\mathrm{MnO}_{2} /$ carbon nanotubes, J. Solid State Electrochem. 23 (2019) 205-214, doi: https://doi.org/10.1007/s10008-018-4122-9.

97. S. Devaraj, N. Munichandraiah, Effect of crystallographic structure of $\mathrm{mno}_{2}$ on its electrochemical capacitance properties, J. Phys. Chem. C 112 (2008) 4406-4417, doi: https:// doi.org/10.1021/jp7108785.

98. J. Li, L. Cui, X. Zhang, Preparation and electrochemistry of one-dimensional nanostructured $\mathrm{MnO}_{2} / \mathrm{PPy}$ composite for electrochemical capacitor, Appl. Surf. Sci. 256 (2010) 43394343, doi: https://doi.org/10.1016/j.apsusc.2010.02.028.

99. J. Ji, X. Zhang, J. Liu, L. Peng, C. Chen, Z. Huang, L. Li, X. Yu, S. Shang, Assembly of polypyrrole nanotube@ $\mathrm{MnO}_{2}$ composites with an improved electrochemical capacitance, Mater. Sci. Eng. B 198 (2015) 51-56, doi: https://doi.org/10.1016/j. mseb.2015.04.004.

100.X. Fan, X. Wang, G. Li, A. Yu, Z. Chen, High-performance flexible electrode based on electrodeposition of polypyrrole/ $\mathrm{MnO}_{2}$ on carbon cloth for supercapacitors, J. Power Sources 326 (2016) 357-364, doi: https://doi.org/10.1016/j.jpowsour.2016.05.047.

101.Q. Lu, Y. Zhou, Synthesis of mesoporous polythiophene/ $\mathrm{MnO}_{2}$ nanocomposite and its enhanced pseudocapacitive properties, J. Power Sources 196 (2011) 4088-4094, doi: https://doi.org/10.1016/j.jpowsour.2010.12.059.

102.J. Chen, C. Jia, Z. Wan, The preparation and electrochemical properties of $\mathrm{MnO}_{2} /$ poly(3,4-ethylenedioxythiophene)/multiwalled carbon nanotubes hybrid nanocomposite and its application in a novel flexible micro-supercapacitor, Electrochim. Acta 121 (2014) 49-56, doi: https://doi.org/10.1016/j. electacta.2013.12.137.

103.P. Lv, Y. Y. Feng, Y. Li, W. Feng, Carbon fabric-aligned carbon nanotube/ $\mathrm{MnO}_{2} /$ conducting polymers ternary composite electrodes with high utilization and mass loading of $\mathrm{MnO}_{2}$ for super-capacitors, J. Power Sources 220 (2012)160-168, doi: https://doi.org/10.1016/j.jpowsour.2012.07.073.

104.F. Liu, Electrodeposition of manganese dioxide in three-dimensional poly (3,4-ethylenedioxythiophene)-poly( styrene sulfonic acid )- polyaniline for supercapacitor, J. Power Sources 182 (2008) 383-388, doi: https://doi.org/10.1016/j. jpowsour.2008.04.008.

105.D. Zhao, Z. Yang, E. S. Kong, Carbon nanotube arrays supported manganese oxide and its application in electrochemical capacitors, J. Solid. State. Electr. 15 (2011) 1235-1242, doi: https://doi.org/10.1007/s10008-010-1182-x.

106.J. Myoun Ko, K. Man Kim, Electrochemical properties of $\mathrm{MnO}_{2} /$ activated carbon nanotube composite as an electrode material for supercapacitor, Mater. Chem. Phys. 114 (2009) 837-841, doi: https://doi.org/10.1016/j. matchemphys.2008.10.047.

107.Y. Liu, D. Yan, R. Zhuo, S. Li, Z. Wu, J. Wang, P. Ren, P. Yan, $Z$. Geng, Design, hydrothermal synthesis and electrochemical properties of porous birnessite-type manganese dioxide nanosheets on graphene as a hybrid material for supercapacitors, J. Power Sources 242 (2013)78-85, doi: https://doi. org/10.1016/j.jpowsour.2013.05.062.

108. M. Kraljić Roković, G. Ljubek, M. Žic, J. Popović, Electrochemical characterisation of sol-gel derived $\mathrm{SnO}_{2}$ for supercapacitor application, Croat. Chem. Acta 290 (2017) 289-295, doi. https://doi.org/10.5562/cca3180.

109.P. J. Sephra, P. Baraneedharan, M. Sivakumar, T. D. Thangadurai, K. Nehru, Size controlled synthesis of $\mathrm{SnO}_{2}$ and its electrostatic self- assembly over reduced graphene oxide for photocatalyst and supercapacitor application, SCMater. Res. Bull. 106 (2018) 103-112, doi: https://doi.org/10.1016/j. materresbull.2018.05.038.

110.S. P. Lim, N. M. Huang, H. N. Lim, Solvothermal synthesis of $\mathrm{SnO}_{2} /$ graphene nanocomposites for supercapacitor application, Ceram. Int. 39 (2013) 6647-6655, doi: https://doi. org/10.1016/j.ceramint.2013.01.102.

111.S. Ren, Y. Yang, M. Xu, H. Cai, C. Hao, X. Wang, Hollow $\mathrm{SnO}_{2}$ microspheres and their carbon-coated composites for supercapacitors, Colloid. Surf. A Physicochem. Eng. Asp. 444 (2014) 26-32, doi: https://doi.org/10.1016/j.colsurfa.2013.12.028.

112.S. N. Pusawale, P. R. Deshmukh, C. D. Lokhande, Chemical synthesis of nanocrystalline $\mathrm{SnO}_{2}$ thin films for supercapacitor application, Appl. Surf. Sci. 257 (2011) 9498-9502, doi: https://doi.org/10.1016/j.apsusc.2011.06.043.

113. R. K. Selvan, I. Perelshtein, N. Perkas, A. Gedanken, Synthesis of hexagonal-shaped $\mathrm{sno}_{2}$ nanocrystals and $\mathrm{SnO}_{2} @ \mathrm{C}$ nanocomposites for electrochemical redox supercapacitors, J. Phys. Chem. C 112 (2008) 1825-1830, doi: https://doi. org/10.1021/jp076995q.

114. M. Wu, L. Zhang, D. Wang, C. Xiao, S. Zhang, Cathodic deposition and characterization of tin oxide coatings on graphite for electrochemical supercapacitors, J. Power Sources 175 (2008) 669-674, doi: https://doi.org/10.1016/j.jpowsour.2007.09.062.

115.R. Li, X. Ren, F. Zhang, C. Du, J. Liu, Synthesis of $\mathrm{Fe}_{3} \mathrm{O}_{4} @$ $\mathrm{SnO}_{2}$ core-shell nanorod film and its application as a thinfilm supercapacitor electrode, Chem. Commun. 48 (2012) 5010-5012, doi: https://doi.org/10.1039/c2cc31786a.

116.S. Kuo, N. Wu, Composite supercapacitor containing tin oxide and electroplated ruthenium oxide, Electrochem. Solid-State Lett. 6 (2003) A85-A87, doi: https://doi. org/10.1149/1.1563872. 


\section{SUMMARY \\ Active Materials for Supercapacitors Application \\ Gabrijela Ljubek ${ }^{a^{*}}$ and Marijana Kraljić Rokovićb}

In the last decade, significant breakthrough has been achieved in both the field of active materials and the design of supercapacitors. Herein, we give an overview of the recent advances in this field, and point out the main groups of material that are characterized by the charge-storage mechanism. From the available research literature, it may be concluded that a fundamental understanding of the charge-storage mechanism as well as determining the relationship between the structural properties of materials and electrochemical performances is important for successful development of supercapacitor. The mechanism insight enables targeted material design and the possibility of combining different electrodes that affect the final properties and application of supercapacitor. The most important materials for supercapacitor application are carbon-based materials, conducting polymers, and metal oxides.

\section{Keywords}

Active material, capacitance, metal oxides, pseudocapacitance, carbon,

conducting polymers, supercapacitor

a Faculty of Mining, Geology and Petroleum Engineering, Pierottijeva 6, 10 000, Zagreb,

Review

Croatia

${ }^{\mathrm{b}}$ Faculty of Chemical Engineering and

Technology, Marulićev trg 19, 10000 Zagreb,

Croatia

Received September 6, 2019

Accepted September 23, 2019 